
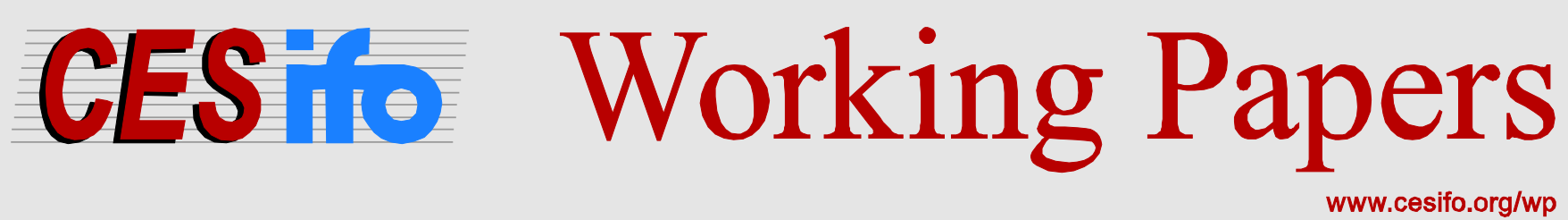

\title{
Smoothing Asymmetric Shocks vs. Redistribution in the Euro Area: A Simple Proposal for Dealing with Mistrust in the Euro Area
}

\author{
Heikki Oksanen
}

\author{
CESIFO WORKING PAPER NO. 5817 \\ CAtegory 6: Fiscal Policy, Macroeconomics AND GrowTH \\ MARCH 2016
}
An electronic version of the paper may be downloaded
- from the SSRN website:
- from the RePEc website:
- from the CESifo website:
wWw.SSRN.com
www.RePEc.org
www.CESifo-group.org/wp

ISSN 2364-1428 


\title{
Smoothing Asymmetric Shocks vs. Redistribution in the Euro Area: A Simple Proposal for Dealing with Mistrust in the Euro Area
}

\begin{abstract}
The euro area will not have a centralised budget and smoothing of country-specific asymmetric shocks via private financial markets will develop only slowly. Mistrust among the governments has caused rigid, even pro-cyclical fiscal policies. Smoothing mechanisms are absent due to the fear that the transfers would develop into permanent redistribution. For removing these deficiencies we propose a transfer mechanism to be managed in periods of seven years so that the cumulative balance of each country is cleared in equal instalments during the subsequent 7year period. The transfers would smoothen asymmetric shocks and alleviate the rigidity of the fiscal rules.
\end{abstract}

JEL-Codes: E420, E620, H100.

Keywords: euro, monetary union, smoothing shocks, fiscal transfers, government budget.

\author{
Heikki Oksanen \\ University of Helsinki \\ Helsinki / Finland \\ hkk.oksanen@gmail.com
}

This version 2016-03-22

A preliminary version of this paper was presented at the CESifo-VIU Workshop 'Rethinking the need for a fiscal union in the euro zone', Venice, 24-25 July 2015. I am grateful for many useful comments received there and from several colleagues afterwards, especially from an anonymous referee and Roel Beetsma and Shafik Hebous as the organisers of the workshop and as guest editors of the special issue of the CESifo Economic Studies.

To be published also in a special issue on fiscal union of the CESifo Economic Studies, 2016.

Accompanied by a separate Technical appendix available at https://www.researchgate.net/profile/Heikki_Oksanen. 


\section{Introduction}

In preparations for adoption of the euro it was frequently asked whether the emerging monetary union should be accompanied by a financial transfer mechanism between the member economies. This entails two equally important issues: (1) how large redistributive transfers are needed to reduce disparities in per capita income levels across the member states, and (2) is there a need to cushion the effects of so-called asymmetric shocks as the exchange rate would no longer be an economic policy tool of individual countries. Especially for the latter, the question was posed with reference to the United States where the federal budget was estimated to cushion about 10-20\% of an idiosyncratic change in income of an individual state.

The MacDougall Report of 1977 called for a Community budget of at least 5-7\% of Community GDP, a considerable degree of fiscal federalism and significant redistribution to reduce income disparities (Commission of the EC 1977, 12). This view did not prevail in preparing and launching the euro in the 1990s. The Delors Committee of 1989 emphasised the need for redistribution, but accepted that the Community budget would remain small and was content with doubling the volume of regional and structural funds foreseen at the time. It also took the view that coordination of national budgetary policies was sufficient for dealing with short-term disturbances (Committee for the study of EMU 1989, 19). This view became subsequently widely accepted. Eliminating the exchange rates across the member states as such was considered to reduce country-specific shocks, partly because disturbances in the exchange rates were considered to have been one of the sources of adverse developments. Also, the single currency was considered to enhance flexibility of the markets, especially the financial and labour markets, and thereby to reduce asymmetric developments.

This was in a nutshell the thinking when moving towards the EMU was agreed in Maastricht in December 1991. The issues regarding redistribution and smoothing asymmetric shocks were nearly forgotten for the first decade of the euro while attention was almost entirely focussed on implementing the principles of sound public finances à la Maastricht.

The old issues then returned to the political arena when the severe financial and economic crisis hit Europe in 2008, and especially when it extended to Greece and some other members of the euro area in 2010. Supporting the weak members financially became a thorny issue, although it never led to proposals for increasing the EU budget to the size proposed by the MacDougall report. New but much more limited arrangements for the EU budget and transfers were brought into discussion in the report of the four presidents of the central EU institutions published in 2012 (Van Rompuy 2012) and in the parallel report of the European Commission (2012). Alongside of these high-level reports numerous (semi)academic reports on tackling asymmetric developments were then produced, making competing and complementary proposals.

Ensuing views and proposals from the high political level were published in the report on 22 June 2015 by the president of the European Commission with the four other presidents of the EU institutions, entitled Completing Europe's Economic and Monetary Union. It notes again that 'large scale fiscal transfers between members are not foreseen', but calls the member states to aim at converging their economic structures towards the best standards in Europe (Juncker 2015, 7). Fiscal stabilisation for the euro area as a whole is in the forefront of the report, but for smoothing asymmetric shocks the report relies in the first place on risk-sharing via the private sectors. It also says that 'public risk-sharing' should be enhanced in the medium term, but this remains vague (Juncker 2015, 4, 14). The succeeding Communication from the European Commission in October 2015 remains silent on any specific proposals for smoothing asymmetric shocks, announcing that further proposals are 
postponed until a Commission White Paper is delivered in spring 2017. Also, the recent volume of leading economists entitled How to fix Europe's monetary union covers a broad range of relevant issues, but leaves plenty of scope for more specified reform proposals (Baldwin and Giavazzi, eds, 2016),

Regarding the theoretical foundations, both an own currency (and central bank) and redistributive policies (progressive taxes and various public goods and social transfers) are intrinsic elements in building nation states in Europe and elsewhere, but positive economic analysis has not provided convincing arguments why a monetary union (alongside with integrated markets) would require extensive redistribution. The strong views in the MacDougall report of 1977 for significant permanent redistribution were never analytically founded, but rather based on coexistence of these various elements in existing monetary unions. At the end, they made a political judgement regarding a monetary union for which there was no precedence.

Contrary to this, benefits of smoothing asymmetric shocks in a monetary union have been argued on analytical grounds in a large body of literature, recently most concisely by Farhi and Werning (2014), referring extensively to earlier work by Mundell, McKinnon and Kenen in the 1960s. The issue here is about the strength of the arguments in favour of a specific smoothing mechanism managed by public authorities as compared to the argument that private markets support convergence across countries and regions, and that the short-term transfers may turn into permanent redistribution, which may not be politically acceptable. These questions are currently open for the euro area.

Goodhart and Smith $(1993,443)$ considered that failing to make a clear enough distinction between persistent redistribution of income and smoothing the effects of sudden or short-term shocks (regardless of initial income level) blurred both political controversy and academic research. For them, this was a reason why the MacDougall Report was pigeon-holed. Now, more than 20 years later, similar problems in analysis persist and hinder inventing politically acceptable mechanisms for both. Also, making the distinction between common shocks and asymmetric (idiosyncratic) shocks has not always been clear in empirical analysis - separating them in econometric work is not always easy.

In the present paper (and most often in the referred literature) redistribution means financial flows for reducing income disparities across the member states. It is normally based on income levels and it is basically permanent in the meaning that the flows continue as long as the underlying income disparities prevail. It can result from deliberate policy measures or as an unwanted side effect of other policies.

Smoothing the asymmetric shocks aims at dampening short- to medium-term fluctuations, in both directions and at all income levels. 'Smoothing shocks' is here a short expression for 'smoothing the effects of shocks'. If these effects are measured by movements in income level, GDP or other macroeconomic variables like the unemployment rate, then no distinction is made regarding the underlying factors. They can be external to the economy (oil prices) or originate from inside the country. Asymmetry may arise from different shocks hitting each country or from the same external shock hitting the counties differently, a simple example being the price of oil or gas which naturally affects the countries differently depending on their degree of oil/gas dependency or being an oil/gas producer.

Here we use the term 'smoothing asymmetric shocks' referring to short- to medium-term movements, noting that the literature often calls it 'insurance' against adverse events, or 'risk sharing'. Smoothing 
can in the extreme case, as to be shown in this paper, be designed so that it strictly avoids redistribution over a defined period of time. Insurance contracts most often also offer smoothing of the effects of a shock, but by their nature they normally lead to a permanent transfer to the entity that happened to be hit by the adverse shock. As an example, fire insurance covers the damage to a house and the compensation to the insured household can be a multitude of what they would have paid as insurance premiums over the whole life time. So, under an 'insurance' scheme the agent buys protection against a risk, and the ex post outcome can be a permanent transfer depending on the realisation of the risk.

As firm political decisions set strict limits to permanent redistribution across the euro area member states, we focus in the present paper on mechanisms that smooth shocks but strictly avoid permanent redistribution.

Analysis starts with the key observation by Allard et al. (2013, 14-15) and others that fiscal policy has rather become pro-cyclical than smoothed the shocks (common and asymmetric) under the euro. This is puzzling as fiscal policy in the euro area, including built-in stabilisers, could have smoothened the short-term shocks, roughly speaking, to the same extent as the federal budget transfers in the US. As an increased rigidity in fiscal policy was neither intended nor expected, we try to find the driving factors from the history of the euro and refer to certain general theories of European integration.

In short, without disregarding other explanations, it is the view here that rigidity in fiscal policy has followed from suspicion and mistrust among the partners. Establishing the euro has been far from smooth collaboration for a common good and sharing the benefits under mutual trust.

This view complements the neofunctionalist approach, which focuses on the spillover effects from one policy area requiring more integration in adjacent fields, as explained by Heipertz and Verdun (2010, 8-12). This would mean here that the single market led to the single currency in order to deliver common benefits more efficiently. The additional benefits can then be shared in a collaborative atmosphere. In parallel, the decisions are driven by less comfortable power struggles between the governments, fuelled by domestic politics in each country. For example, the frequent realignments under the Exchange Rate Mechanism (ERM) were embarrassing for many member states as they demonstrated the supremacy of the Bundesbank. For this reason the Bundesbank, the anchor of the ERM, had to be Europeanised. The opportunity arose at the Strasbourg summit in December 1989 when Germany was about to be reunified, right after the fall of the Berlin Wall. Its partners gave their consent, saying that it 'should take place peacefully and democratically ... [and] to be placed in the perspective of European integration'. The latter phrase then appeared to imply an obligation to join the planned monetary union, applying first and foremost to Germany. A politically agreed obligation compensated for a deficient level of trust.

Delivering this large package required including the provisions on budgetary discipline into the Treaty agreed in Maastricht in December 1991. However, the purpose of the excessive deficit procedure (EDP) to act 'in view of identifying gross errors' (TFEU 126) was not fully satisfactory for the German Constitutional Court. It ruled in 1993 that the EMU in the Maastricht Treaty is compatible with the German constitution only on the condition that fiscal discipline prevails expressly firmly (Schmidt 2013, 1-8; Tuori and Tuori 2014, 200). This and concerns expressed among German public and economists led to strengthening the assurances of fiscal discipline in the Stability and Growth Pact (SGP) adopted in 1997. 
This history shows how suspicion and mistrust among the partners led to the SGP and its strict implementation, which then contributed to rigidity that caused the decrease in smoothing shocks and even pro-cyclicality of fiscal policies. ${ }^{1}$

In addition, mistrust seems to explain why it has been practically impossible to agree on any specific mechanisms for smoothing short-term shocks as the suspicion that they would lead to permanent redistribution has been so intense. The recent high-level reports indicate that no proposals are soon expected on this front.

Thus, improvements in the EU fiscal mechanisms and rules require building more trust. The current severe crisis is certainly not a good moment to make progress in this regard as the crisis treats the countries differently. But at the same time, a pragmatic approach is to tackle the issues one by one, provided that they are sufficiently distinct from each other.

In this spirit we outline in the present paper a specific mechanism for smoothing asymmetric shocks such that permanent redistribution is strictly eliminated by a specifically designed rule. This may indirectly support tackling also other pertinent issues in the euro area. Diminution of asymmetries could help the decision makers to concentrate more accurately than hitherto on setting the fiscal and monetary policy stance, not only for the individual members but for the euro area as a whole.

The paper proceeds as follows. In section 2 we review of the literature covering redistribution and smoothing of asymmetric shocks presented alongside with preparation of the Economic and Monetary Union (EMU), followed by summarising the views among professionals on how the current euro area crisis arose, complemented by listing the proposals for alleviating the asymmetric shocks presented in the last few years. Section 3 provides the simplest possible model for conceptual clarification of permanent redistribution of income in favour of less advanced countries of the euro area and smoothing asymmetric shocks which may partly occur as a by-product of redistribution. In section 4, having noted the limits to politically acceptable redistribution across the EU member states, it is shown that even if the currently operating redistributive schemes in the EU were modified for maximal smoothing in the short term as their by-product, it would remain virtually negligible.

In section 5, inspired by the conclusion above, we design a simple smoothing mechanism for the euro area that would strictly, by construction, avoid permanent redistribution. The underlying hypothesis is that strict prevention of redistribution is necessary for overruling the suspicion that the mechanism could lead to permanent transfers. It will be noted that the resulting risk-sharing is suboptimal as compared to theoretical models, but this is an unavoidable consequence of mistrust. As required of any new proposal, we shall assess whether the same effect could be achieved by other means, with the conclusion that this is not likely. Section 6 will give the summary and conclusions.

While Györffy $(2013,10-11)$ focuses on the importance of institutional trust for enhancing long-term decision making by private sector agents, in our paper we specifically emphasise the role of trust, or rather mistrust among the member governments of the euro area as a factor to be acknowledged and dealt with. 


\section{A brief history of the literature and the evidence}

\subsection{Preparing the Maastricht Treaty}

The famous MacDougall Report of 1977 reviewed the size of public budgets in monetary entities like the US and European states and analysed redistribution of income between their regions and cushioning of the effects of asymmetric shocks.

The 'presumably at some distant date' vision of the MacDougall group was a Federation in Europe with federal public expenditure around 20-25 per cent relative to GDP. The group set aside this distant vision and focused on the various stages building up sufficient support for a monetary union. For the group, in 'present circumstances', with a Community budget of $0.7 \%$ of GDP of the nine member states as it was at the time, monetary union was 'impracticable' (Commission of the EC 1977, 12).

Then, the group envisaged an increase of the Community budget to $2-2 \frac{1}{2} \%$ of GDP in the pre-federal stage. If the budget were carefully designed, it could reduce income disparities by $10 \%$ (meaning that as the income level in the less advanced parts of the Community, assumed to cover $20-25 \%$ of the population, was $60 \%$ of the average, a transfer should top their income to $66 \%$ of the average; this would have cost $1 \%$ of the Community's GDP at the time, see Commission of the EC, 1977, 16, 6869). For the group this could have only been an acceptable start for income equalisation, but definitely not sufficient for sustaining a monetary union. Instead, as they noted that in the member states and other countries they studied regional equalisation was four times greater, the group considered that a common budget of at least 5-7 \% of GDP was required (or 71/2-10 \% of GDP if defence was to be transferred to the Community level), and even this was sufficient only if the budget was carefully designed to serve both income equalisation and cushioning temporary fluctuations (Commission of the EC 1977, 13-18; MacDougall 1998, 65). ${ }^{2}$

Twelve years later the Committee for the Study of Economic and Monetary Union (1989) chaired by Commission President Jacques Delors emphasised in its epoch-making EMU blueprint the need to 'spread welfare gains throughout the Community' and warned that 'if sufficient consideration were not given to regional imbalances, the economic union would be faced with grave economic and political risks'. Delors himself had produced a paper on this topic accompanying the report, pursuing the same arguments as the MacDougall Report (Delors 1989, 88).

The Delors Committee underlined the need for 'narrowing regional and structural disparities', but it concentrated even more on designing the other parts of the EMU, especially the monetary part. It accepted to launch the single currency with a small Community budget and limited transfers, comforting with doubling the Structural and Regional Funds foreseen at the time (Committee for the study of EMU 1989, 18). The Committee mentioned also the issue of cushioning the asymmetric shocks but did not propose any particular mechanism.

The summit in Strasbourg in December 1989 welcomed German unification, calling for to happen peacefully and democratically. It also endorsed the Delors Committee report and decided on convening the Intergovernmental conference to draft the EMU Treaty.

2 As the EU budget remained small (on the order of magnitude of $1 \%$ of GDP as today) Sir Donald MacDougall opposed strongly the adoption of the euro in the 1990s and naturally was against the participation of the UK. 
The equally famous One market, one money report by the EC Commission followed in 1990. The main understanding regarding the future size of the Community budget was repeated: it is not realistic even to contemplate a significantly increased Community budget (Commission of the EC 1990b, 101). The report discussed the benefits of a centralised Community budget for fiscal transfers and shock-absorption, weighing them against the benefits of fiscal autonomy of the member states, noting that this is a trade-off and the choice had to be left open (Commission of the EC 1990b, 166-169). Regarding possible mechanisms for shock-absorption the report referred to the studies in the accompanying volume by Van der Ploeg (1991, 143-146, 158) and Wyplosz (1991, 179-182), which suggested interpersonal redistribution schemes to cope with unemployment in depressed regions hit by adverse shocks. In their proposals the transfers would go down to the level of individuals instead of the budgets of the member state or regional authorities. ${ }^{3}$

The One market, one money report considered that the monetary union would reduce asymmetric developments by enhancing flexibility of the markets, including the labour markets, while giving a positive role also for an increased volume of the regional and structural funds.

The Maastricht summit in December 1991 agreed on the EMU chapter in the new Treaty along these lines.

\subsection{Comparing the emerging EMU to shock absorption in the US}

In parallel with the Delors report and One market, one money academics started to ponder the viability of the single currency by looking at the seriousness of the asymmetric shocks in the European economies. Obviously, the $1 \%$ of GDP EU budget provided no basis for automatic cushioning, and the proposals to gear some Community mechanism for this purpose remained meagre. Also, the proposals for increasing the regional and structural funds would by their nature not help cushioning shocks in the whole monetary union but mostly only covered the least advanced countries and regions.

In these studies the US was taken as a benchmark, estimating the proportion of the state-specific shocks smoothed out by the federal budget. Sachs and Sala-i-Martin (1989) laid the ground with their finding that the degree of cushioning was one third (Sachs and Sala-i-Martin 1992). For them, lacking this element put the viability of the single currency for the EU into question. von Hagen (1992) challenged their result by pointing out that they had mixed up redistribution and shock absorption. According to him the smoothing effect by the US federal budget was less than ten per cent. This supported his view that a European monetary union does not require a specific mechanism for this purpose.

Due to so divergent estimates and the importance of the issue a large body of literature flourished. The views converged after Pisani-Ferry, Italianer and Lescure (1993) estimated that net transfers from

3 Regarding shock-absorption in the EMU, Van der Ploeg wrote: 'If the people in Europe are not willing to introduce [a European federal transfer scheme] individual countries have a duty to pay much more attention to structural supply-side policies in order to ensure that national labour markets adjust more quickly to full employment' (Van der Ploeg, 1991, 158). In the same volume Van Rompuy, Abraham and Heremans $(1991,133)$ took the view that a possible transfer mechanism for cushioning asymmetric shocks would require close surveillance on the economic performance of the eligible member countries. 
the US federal budget compensate for $17 \%$ of a regional shock. This order of magnitude, i.e. a 15-20 $\%$ smoothing of the effect on state income, was later confirmed in several studies.

Most recently, Poghosyan, Senhadji and Cottarelli (2015, 63-65), review the past estimates of redistribution and smoothing of asymmetric shocks in federations and unitary countries, and present new estimates for the US, Canada and Australia. For smoothing asymmetric shocks (which they call risk sharing) the authors find for the US five per cent with one method and 12-13 per cent with two other methods, and quite low estimates for the other two federations. The 12-13 per cent result for the US is not badly out of line with previous studies, but especially for the other two federations they are. They first estimate the combined reactions to common and asymmetric shocks, and then estimate the latter alone. The result is that smoothing of the common shocks (that they call 'stabilisation') dominates, while smoothing of asymmetric shocks is $12 \%$ for the US and negligible for Canada and Australia (Poghosyan, Senhadji and Cottarelli 2015, 74-76, 78-81; also Cottarelli and Guerguil 2015, 5-6). These results deviate from most previous studies. It seems that separating the effects of common and asymmetric shocks has failed, and due to the dominance of common shocks in their samples the estimates for the asymmetric effects are biased downwards. ${ }^{4}$

In the studies at the time of preparations for the EMU the US was the main benchmark, although the smoothing effects of federal or central budgets in other countries (Germany, France and others) were also estimated. Commonly, the results were of the order of magnitude of $40 \%$ being smoothed. This can be considered quite plausible, taking into account the size of the federal/central budgets and their main features regarding taxes and transfers in European welfare states. ${ }^{5}$

\subsection{Smoothing induced by cross-ownership of capital and saving and borrowing}

Asdrubali, Sørensen and Yosha (1996) and Sørensen and Yosha (1998) opened a new line of research on variations in gross state product and income in the US by taking into account cross-ownership of capital by the private sector. A negative exogenous asymmetric shock on a particular sector of production in one state would be alleviated by cross ownership, as part of the fall in capital income

4 The difficulty with the estimates can be illustrated with a simplified case: assume that federal expenditure is $20 \%$ of total income and that, given no common shock and hence no change in the federal government deficit, it is financed by proportional taxation; then the smoothing effect is $20 \%$ if and when an asymmetric income change takes place (for one relatively small state). This same effect would be there even if a common shock took place and the federal government deficit covered the lost net revenue. If this simple case even remotely resembles the real world, smoothing of asymmetric and common shocks take place in parallel and the result that asymmetric shocks are not smoothed at all or just below $10 \%$ must be biased. - The importance and difficulty of making the distinction between asymmetric and common shocks was already emphasised by Fatas (1998) who endorsed the estimate of $10 \%$ smoothing in the US by von Hagen (1992).

5 The literature was reviewed in the 1990s by Obstfeld and Peri (1998, 236-239) and Mélitz and Zumer (1998). The wide variety of estimates sometimes caused confusion as different authors referred to different measures of product or income. Typically, in the US gross state product varies more than gross income because net factor income flows between the states smoothen some of the variations. Each variant is interesting as such. Estimates of 15-20\% for smoothing came out from several studies. The more detailed results depended to some extent on the origin of the shock. Given a fall in exports for example, the impact on tax revenues is smaller than in the case of a fall in consumption. For more recent reviews of the estimates see von Hagen (2007) and Poghosyan, Senhadji and Cottarelli (2015). According to a recent study by Dolls, Fuest and Peichl (2012) the automatic stabilizers absorb 32 per cent of a proportional income shock in the US, and this cushioning of disposable income leads to a demand stabilization of up to 20 per cent in the US. 
would be felt by residents of other states as they hold part of the equity. In addition, both saving and investment in each state adjust so that net lending between them smoothens the effect of a shock this is called the 'credit channel' or 'saving and borrowing channel'. This takes place in the US mainly in the private sector as the state budgets are close to being balanced. In the subsequent analysis for the EU it was correctly noted that in the euro area most of the credit channel works through fluctuations in government borrowing from the international markets.

In a recent short paper Hoffmann and Sørensen (2012) summarise the estimate for the US as follows: capital incomes smooth $40 \%$, credit markets $25 \%$ and the federal-level fiscal transfers $10-15 \%$ of the variation. This leaves only $20-25 \%$ unsmoothed. They note that in the EU countries (and OECD countries more generally) cross-ownership of capital is tiny, fiscal transfers between the countries negligible ( $1 \%$ for the EU) and the credit channel smoothens $25 \%$ of the variations.

In their papers in the 1990s Sørensen and his colleagues argued that the prospects of the euro were doubtful. For them the reason was not so much the lack of the federal budget but rather the lack of an integrated capital market. Repeating this, Hoffmann and Sørensen (2012) consider that the best way to uphold the viability of the euro is not to establish a fiscal union (which would anyhow only take care of a small fraction of the problem) but to make legislative and other improvements in the EU (including harmonisation of tax laws) so that smoothing through the capital market starts working.

\subsection{Interpretation of the EU fiscal rules required a judgement of the EU Court}

The estimates by Sørensen and his colleagues are referred to and confirmed by an IMF team and published by Allard et al. (2013; also 2015), together with the supporting report Towards a fiscal union for the euro area (2013). Their basic finding is that in the euro area, smoothing, taking the three channels together, is between one third and $40 \%$, i.e. half of the effect in the US. Most of it stems from the credit channel, and this comes mainly through the built-in stabilisers in the general government budgets. Less than $10 \%$ comes from sharing the variations though the capital income channel (Allard et al., 2013, 14-15; Towards a fiscal union for the euro area, 2013, 8-9).

Their important new finding is that the degree of smoothing has decreased under the euro: it was two thirds in 1979-1998, but then declined to one third. According to their analysis the credit flows have been more pro-cyclical than before the EMU partly due to 'the underpricing of risks by markets that characterized the first decade of EMU, in a context of over-optimistic growth expectations' (Towards a fiscal union..., 2013, 10-13). Allard et al. $(2013,11)$ also note that implementation of the EDP and the SGP targets apply to the headline fiscal balance and therefore does not take into account the cyclical position. This has proved suboptimal as the deficit ceiling of three per cent of GDP is easily complied with under favourable economic conditions, but the countries are forced to unduly tighten their fiscal stance during downturns to meet this same target. In line with this, Furceri and Zdzienicka (2013) find that smoothing ('the effectiveness of risk sharing mechanisms') in the euro area is not only significantly lower than in existing federations (such as the U.S. and Germany) but also 'falls sharply in severe downturns just when it is needed most'. Also according to Eyrand and Wu (2015) fiscal policy has been pro-cyclical most of the time during the euro.

Looking at the diminished smoothing effect of government budgets noted by Allard et al. (2013) and others we come to the heart of the fiscal rules for the euro. Implementation of the EDP and SGP always requires making a reasonable compromise between short-term flexibility and maintaining long-term sustainability of public finances. 
In the reports preparing for the single currency in 1989-1993 the importance of the credit channel through built-in stabilisers in government budgets was only vaguely mentioned here and there. ${ }^{6}$ Based on today's understanding, neglecting the issue of smoothing the asymmetric shocks in the Maastricht Treaty could have argued as follows: in the US the federal budget smoothens 15-20\% of the shocks but the budgets of the US states are rigid and do not contribute in this regard; conversely, in the euro area the built-in stabilisers in the government budgets smoothen the asymmetric shocks by at least the same amount as the US federal budget - this flexibility is part of what the academics later started to call the credit channel; thus, a large budget for the euro area is not needed for cushioning asymmetric shocks; reducing income disparities permanently is another matter, but as the persistent differences in the US are almost as large as between the EU counties, lack of redistribution should not be an obstacle to the EMU.

This line of argument was not in the forefront in the early 1990s possibly partly due to the reassurances in the One market, one money report and elsewhere that the single currency would sail smoothly as it would eliminate the exchange rate disturbances and promote integration of all markets. Attention was directed to assuring fiscal discipline, which in the Maastricht Treaty appears in several ways, including the excessive deficit procedure (EDP).

When coming closer to launching the euro in 1999 (which was written in the Maastricht Treaty as a date when the single currency starts even if only a minority of the member states participated) the concerns expressed in Germany, including by the German constitutional court, required further assurances that fiscal discipline will prevail and the health of the new currency be guaranteed (Schmidt 2013, 1-8; Tuori and Tuori 2014, 200). This led to adoption of the SGP regulations in 1997, containing the strict deadlines for correcting excessive deficits (although 'as a rule' appearing in the text as the discretionary power of the Council had to be preserved as it is secured by the Treaty).

The SGP were an expression of suspicion and mistrust among the partners and became a source of rigidity in fiscal policies and made it even pro-cyclical. One need not be an economics professor to note that a strict calendar for correcting an excessive deficit is stupid, as Romano Prodi put it in 2002. However, when this was said by the president of the EU Commission, mistrust was amplified and pointing out an obvious problem backfired. Soon after, in 2003, Prodi had to endorse an interpretation of the SGP rules that was later judged to have been even more rigid than was required by the legal provisions in force (see below).

The SGP crisis in 2003 has been persistently referred to in the media and professional publications as violation of the rules by Germany and France. As a recent influential example, this view appears repeatedly in the large CEPR volume The Eurozone Crisis, a Consensus View of the Causes and a Few Possible Remedies (2015) where it is given as a particularly detrimental precedent for SGP failing to prevent the crisis (Baldwin and Giavazzi, 2015, 52; Frankel, 2015, 112; Weder di Mauro, 2015, 179; and Feld et al., 2015, 186). This interpretation has helped to introduce new procedures for disciplining the member states and devoting more power to the central level, either to the EU Council or to the European Commission.

6 Mentioned in One market, one money (Commission of the EC, 1990b, 11, 24, 30 and 136) and in the supporting volume by Pisani-Ferry and Emerson (1991, 17), and by Begg (1991, 218). The report Stable money - sound finances of 1993 (Commisssion of the EC, 1993) is silent about it, and in the supporting volume only Pisani-Ferry, Italianer and Lescure $(1993,524)$ mention it in their conclusions. 
This interpretation is, however, inaccurate and misleading. As this episode is closely related to adjustment to idiosyncratic (and also to common) shocks more generally and obviously affects peoples' perceptions of what went wrong in the euro area and what needs to be improved, it deserves a closer look.

Regarding Germany it was an issue about interpretation of the rules in a situation where it had implemented the previously given recommendations for correcting its excessive deficit, but new adverse factors impeded attaining the target. Germany wanted the previous recommendations to be revised and be given more time to reduce the deficit. Although it is plain common sense that the exogenous economic factors may change so that it is best to modify both the policy measures and the immediate targets for, for example, deficit reduction, the European Commission and some member state finance ministers argued that the rules did not allow this legally and insisted that the sanctioning procedure had to move to the next stage. This dispute was finally judged by the EU Court of Justice (ECJ) that considered that the rules in force at the time would indeed have allowed revising of the previously given recommendations and moving to the next stage in the EDF procedure could have been postponed, as Germany had wanted, if there were acceptable reasons to do so. So, unfortunately for reasonable interpretation of fiscal discipline, the existence of such acceptable reasons was not judged as this was considered superfluous under the restrictive legal interpretation that later turned out to be incorrect. ${ }^{7}$

Thus, there was more room for smoothing the effects of shocks already under the original SGP rules than argued by the EU Commission and some others. The reputation of the EU institutions suffered persistently, especially because the full analysis has been missing and inaccurate descriptions of the SGP crisis of 2003 are still nourishing mistrust.

However, as so often, even this unfortunate episode had its positive facet. After the judgement of the ECJ the SGP was revised in 2005, notably making it explicit that the EDP/SGP steps can be repeated, the recommendations revised and deadlines for correcting excessive deficits extended if unexpected adverse economic events occur, provided that a sound economic rationale can be demonstrated. The revision was probably decisive for allowing flexibility when the financial and economic crisis erupted in 2008. Without commonly agreed flexibility, public finances could have hit a wall and the rules could have collapsed altogether as non-applicable.

7 Beetsma and Oksanen (2008, 565); Korkman (2005, 117, 203); Heipertz and Verdun (2010, 2, 128-162); Oksanen $(2013,223)$. The required qualified majority was not found for any proposal in the ECOFIN Council in November 2003 under a correct legal procedure, but a declaration on the postponement of the deadlines for correction of excessive deficits was adopted by a qualified majority. This declaration was then annulled by the ECJ for procedural reasons. - France did not have similar arguments as Germany, but it also wanted to postpone correction of its deficit. The two cases were dealt with at the same time and the result was an impasse regarding both. - In its ruling, the ECJ considered (by implication) that, legally under the SGP rules in force, the earlier recommendations could indeed have been revised, provided that the European Commission had tabled a revised recommendation; doing this would have allowed postponing moving to the next stage of the EDP procedure as Germany wanted (paragraph 92; for details, see Court of Justice of the EU 2004; Doukas 2005). 


\subsection{Pro-cyclicality before and after entering into the crisis}

In addition to noting that the deficit target of three per cent of GDP applies to the headline fiscal balance regardless of the position in the cycle is suboptimal (Allard et al., 2013, 11), several other sources of pro-cyclical effects of the SGP have been deliberated.

Hers and Sucker (2014) argue that using structural budget balances for measuring fiscal stance has led to pro-cyclical policies as the most recent observations of GDP have had an unduly strong weight in assessing potential output and thereby the structural balance. For example, according to the authors, now that the euro area has suffered from negative or low growth, the estimation method used by the European Commission (agreed with the member states' representatives) has led to excessive pessimism with regard to future GDP, as compared to the estimates by the IMF and the OECD. This feature has then led, or in any case tends to lead, to tightening of fiscal policy: as potential GDP is judged to have declined, the estimated structural component in the headline deficit is large. If on the contrary, the cyclical component had been estimated to be large, then there would have been a case for tolerating larger fiscal deficits for the time being. So, to the extent the policy measures have been based on underestimated potential output and overestimated structural deficit, the policy has aggravated the recessions. As the same bias also works in the boom period, policy becomes systematically pro-cyclical.

McMorrow et al. (2015) respond to the criticism by Hers and Sucker (2014) and others with a broad set of data and estimates. They show that the method employed by the European Commission has performed relatively well and has been superior to the others, though they also admit that continued improvement is desired. One of their key arguments is that the estimate of the European Commission for the EUR-12 output gap for 2009 was smaller than those by the IMF and the OECD, and that the Commission estimate is confirmed by the ex post estimates based on the 2014 data by all the three institutions (McMorrow et al. 2015, 16-17). This is an important observation, but the conclusion may not be fully correct.

Suppose that the output gap estimate was biased downwards and, consequently, the one for the structural deficit upwards, and that this led to tight fiscal policy. Then, tight fiscal policy from 2011 onwards may have been one reason for slow growth in the euro area, slower than in the US, which continued to run twice as large fiscal deficits over 2011-14 (and in fact also 2008-10). According to Baldwin and Giavazzi (2015, 46-48) a large number of leading economists (writing in their CEPR 2015 volume) take the view that this is what happened (Baldwin et al. 2015, 10-11).

If so, the following interpretation is possible: the real time estimate of the output gap of the Commission (smaller than the ones by the IMF and the OECD) was one reason for unduly tight fiscal policy, which then reduced the output even further, and the prolonged recession led to reduced potential output. Then, ex post, all institutions had to lower their estimates for potential output to roughly the same level as the real time estimate of the European Commission in 2009. It is not a questions which estimate in 2009 was right or wrong, but the effect of the estimate of the Commission on policy appears relevant.

Assessing as to how much leeway there was for more accommodating fiscal policies from 2011 onwards is still under heated controversy. Those who defend the policies consider that it was necessary to reduce budget deficits, and the EU rules helped to do so, while the critics maintain that tight policies have made matters worse both in the short and in the long run, and this happened partly due to the SGP rules and their rigid implementation. 
We need to accept that the final verdict cannot be made now or possibly ever. However, there is now a broad agreement that building up the overheating before 2007 was a failure of the SGP and the policies at large, especially with regard to Spain and Ireland, which were running fiscal surpluses in 2003-07 but then entered into a serious crisis.

So, it has become a general view that during the first nine years of the euro (1999-2007) the SGP rules received excessive attention, which together with overly optimistic views of potential output fuelled pro-cyclical policies in the euro area as a whole. This is a relevant remark for the analysis of the asymmetric shocks as the same reasoning implies aggravating the differences in their cyclical positions. Most directly this conclusion applies to the countries that were hit by the especially severe recessions, without forgetting that at least in Spain and Ireland overheating before the crisis was fuelled by the asset markets.

\subsection{Greece as a special case}

Mistaken identification of the origins of the Greek crisis can lead to ineffective remedies or even to further mistakes. The origin was not breaching budgetary discipline when it had become a member of the euro area, but rather that it was allowed to join at all in 2001. Olli Rehn $(2012,37)$, the vicepresident of the European Commission at the time of publishing his book, wrote that an unnamed ECOFIN Council minister conveyed to him that in 2000 when they unanimously welcomed Greece they knew that it did not satisfy the criteria. Also Valéry Giscard d'Estaing later said that the French government in particular insisted on it (while he himself was against it; EurActiv.com, 23 Feb 2015). France obviously wanted to increase the voting power of the Mediterranean block in the euro area. Rehn dismissed the responsibility of the European Commission, ignoring that the Council decision was taken on the basis of its convergence report (together with the parallel report from the ECB). ${ }^{8}$

It is important to note that it was not Greece who decided its acceptance to the euro area, but rather it was the initial members and the European Commission who did so. According to Eichengreen and Wyplosz (2016b) acknowledgement of the collective responsibility at the eruption of the Greek crisis in 2010 could have led to more efficient policies and the prolonged austerity could have been avoided. The final verdict will remain open, but a correct picture of the origin of the problem also weakens the arguments for tightening fiscal discipline in the short term and shifts the focus on the health of the fiscal institutions and sustainability in the long term.

In this regard it is telling that Greece was the only EU member state that did not participate in the first two rounds of reports on population-ageing-related public expenditures in 2001 and 2006 undertaken jointly by the European Commission and the member states. When they finally joined the 2009 exercise, their public pension expenditure was projected to increase to 24.1 per cent of GDP by 2060, the highest level in the EU. Correcting this then became an important part of the conditions under which the EU and International Monetary Fund provided financial support (under the arrangements that went grossly beyond the EMU fiscal rules).

8 It also remains for history writers to verify what the European Commission did and did not do in spring 2000 when it failed to inspect accurately the Greek government accounts and proposed to accept Greece to the euro area. 


\subsection{The ECB and TARGET2 as a credit channel}

According to Baldwin and Giavazzi $(2015,20)$ one of the original faults in designing the euro system was that there is no lender of last resort and that the ECB was even explicitly forbidden to play this role. We may note once again that this followed from mistrust: lending by the ECB to governments was restricted in order to make sure that they do not misbehave. No distinction was made between lending to a government for consumption and expenditures for rescuing banks in a crisis. The euro system had to learn the consequences of this limitation in the hard way when the euro entered into the second phase of the crisis in 2012. Only the declaration of the ECB Governor in July 2012 that 'the ECB is ready to do whatever it takes to preserve the euro' turned the tide. The ECB announcement of the 'outright monetary transaction' (OMT) followed in September 2012 and became a good enough substitute for the 'lender of last resort' and calmed down the looming crisis (Baldwin and Giavazzi, 2016, 28-29). Finally in June 2015, the EU Court of Justice judgement confirmed, as a response to the German constitutional court, that the ECB had not exceeded its mandate. ${ }^{9}$

This episode concerned the survival of the euro, but its origin was in severe asymmetric developments that evolved into a systemic crisis. There was, and there will be in future, issues with the policies of the ECB with regard to the rules which government bonds it accepts for its market operations and the collateral it requires in normal times and when it acts in concert with other institutions in times of specific crisis. All these complex issues are related to dealing with asymmetric shocks, but they are left outside the present paper to be analysed, for example, in the context of a proposed insolvency procedure for sovereigns which aims at disciplining government borrowing by the creditors (Fuest, Heinemann and Schröder 2016; Dolls et al. 2016; Feld et al. 2016).

For our study we should note another domain under the ECB, TARGET2, as an extensive mechanism whereby it intermediates funds between the member states (Allard et al. 2013, 15). It became the credit channel to fill the gap when private lending to governments (notably Greece) and the private sector (notably Spain) ceased and reversed (Lane 2015, 131). At the peak of TARGET2 balances in August 2012 the German central bank provided credit amounting to $27 \%$ of Germany's GDP, having increased it over the previous 12 months by $13 \%$ of its GDP, while the negative balance of Spain was at the same time $40 \%$ of its GDP, having increased over the previous 12 months by $34 \%$ of its GDP. The negative balance of Greece was in August $201257 \%$ of its GDP.

The peak level of credits through TARGET2 subsequently contracted, but increased again slightly after the summer of 2014, and the credit positions remain far greater than crisis financing from the European Financial Stability Facility (EFSF) and the newly created European Stability Mechanism (ESM). TARGET2 is an example of how a public body steps in when the normal economic institutions cease to function properly. It was not foreseen that the Eurosystem would channel such important credits flows from countries with current account surpluses to those in deficit, even

9 Court of Justice of the EU (2015a and b). From the point of view of economics it is interesting to note that one of the arguments of the EU Court was that the OMT programme never had to be activated as the announcement as such turned out to be sufficient for restoring 'the monetary policy transmission mechanism': stabilising expectations and perceptions may do the trick and make tangible intervention unnecessary. 
temporarily. This came about in a crisis, without prior design, as smoothing of asymmetric shocks remained as a secondary issue when the institutions for the euro were established. ${ }^{10}$

\subsection{Early proposals for specific smoothing mechanisms}

As noted above, several proposals for smoothing asymmetric shocks were discussed in the various reports in 1990-1993. Van der Ploeg (1991) and Wyplosz (1991) presented preliminary views in their background studies for One market, one money, followed by more specified and quantified proposals in 1993 in the Stable money - sound finances report compiled by a group of independent experts (Commission of the EC 1993). According to the synopsis of the accompanying volume (European Commission 1993), most writers dealing with this problem were 'definitely in favour of Community assistance to Member States for stabilisation purposes' (p. 16). It was also recognised that this was not an easy task. In the accompanying volume Mahocchi and Rey (1993) proposed, under the political and financial constraints, a limited ad hoc scheme providing for a country hit by a serious adverse shock with a transfer of at most $1 \%$ of GDP of the recipient, with an absolute maximum set at $0.3 \%$ of the GDP of the largest country (Germany); this bias in favour of smaller countries was based on the view that the small countries are more vulnerable to shocks.

In the same volume Goodhart and Smith $(1993,437)$ cautiously considered 'that a practical and beneficial stabilization scheme could be designed within the parameters that the Community will wish to operate, i.e. without a federal income tax'. Nevertheless, 'any effective stabilisation scheme must, by its very nature, imply large fluctuations, between deficit and surplus, in the European Community budget'. They left further details open.

The Stable money - sound finances report gives great prominence to a proposal based on unemployment rates (Commission of the EC 1993, 7, 73-78), detailed in the accompanying volume by Italianer and Vanheukelen (1993). The basic idea is that a member state hit by a negative shock receives a transfer based on 'the monthly year-on-year increase in unemployment vis-à-vis the Community average'; one percentage point gives a monthly payment equal to one twelfth of the previous year's GDP. This was capped at $2 \%$ (they also presented a slightly different variant with a threshold). The cost of the scheme is illustrated using unemployment data over the previous decade, with the result that the cost of both variants would have been $0.2 \%$ of Community GDP on average over 1981-1990. The study group praised the scheme as very efficient, writing that 'unlike 'automatic stabilisers' in existing federations the proposed system is explicitly designed for regional stabilization purposes, rather than being a by-product of redistributing programmes'. The authors and the group assert that the implied degree of smoothing asymmetric shocks is close to $20 \%$ which compares well with the results in various studies (see above) for the US and Canada (Commission of the EC 1993, 7, 75-76).

At a closer look, this comparison with the degree of smoothing in existing federations is exaggerated. As in the proposal the transfer is based on the year-on-year change of the underlying variable, the mechanism produces a stabilising effect for 12 months only, while in the existing federations where smoothing is a by-product of progressive income tax and related transfers, the effect lasts as long as

10 Sinn $(2012,6)$ has brought up the risk of the Northern euro area members suffering huge losses from their TARGET 2 credits which may not be fully protected legally in the case of a euro break up. He notes that this risk may already worsen their credit ratings, while he also acknowledges that the TARGET2 flows may reduce harmful effects of financial market disturbances. From the point of view of the present paper, tolerating the credit flows under the TARGET2 may well help in managing the asymmetries and prevent the euro area from breaking up, triggering realisation of much more serious risks for all. 
the underlying shock prevails. So, for example, if the adverse effect prevailed for three years, total smoothing is three times greater.

Even if the Stable money - sound finances report praised this stabilising mechanism as one of its main findings (Commission of the EC 1993, 7), obviously partly due to the exaggerated estimate of its effectiveness, the group did not advocate it strongly, given the other stabilising mechanisms already at work in the EU economies. In fact, Pisani-Ferry, Italianer and Lescure (1993, 513) write: 'stabilisation in EMU at the Community level is less needed than in federations due to the large autonomy of Member States regarding spending and taxation decisions'. This view was in line with the orientation in One market, one money according to which the single currency will not require specific mechanisms because the markets and government budgets will be flexible enough for the single currency to function smoothly.

Although discussion of specific smoothing mechanisms emerged here and there till 1998 when the decision of adopting the euro was taken, ${ }^{11}$ it did not become a major issue until 2012 when the deep crisis brought the need for reforms back into discussion.

\subsection{Recent proposals for smoothing mechanisms}

\section{(a) Unemployment based proposals}

Recently, several proposals based on unemployment rates have been presented, referring to the earlier proposals by Majocci and Rey (1993) and Italianer and Vanheukelen (1993). The report from the Employment and social affairs DG of the European Commission (DG EMPL) reviews six examples, three of them prepared for a workshop arranged for preparing proposals for the European Commission in 2012 (European Commission, 2013a, 19-24). ${ }^{12}$ It is understandable that designing a scheme where a transfer from the common European pool to member states or to their entities (at the extreme down to the level of individuals) is based on the relative unemployment rate has gained support. After all, a comparably high unemployment rate is a commonly understood measure of adverse development.

One tendency in most of these proposals is to try to avoid large financing needs and persistent or permanent transfers to any recipient country or region. Therefore, in some proposals only an increase in unemployment over a specified period (and compared to the average in the EU) is taken as a basis (as it was already in the Italianer and Vanheukelen proposal in 1993), and possibly only the excess over some threshold. In some proposals also the duration of each transfer is limited. These features mean that the scheme does not dampen booms which could, however, be considered to be equally important.

These and various other problems are recognised in many papers, including European Commission (2013) and Beblavý and Maselli (2014) prepared for the European Parliament. A relatively straightforward proposal that avoids many of them is presented by Artus et al. (2013) in their paper

11 An example is the decision of the European Parliament in December 1998 on the eve of launching the euro. It considered that, given asymmetric shocks, 'the EU should have a budget to enable it to take effective action to combat economic slumps' and that 'it would be wise to create an insurance instrument at Community level as a means of last resort' to provide 'credit that has to be repaid with interest' (European Parliament, 1998b, 34). Interestingly, this fairly modest position of the European Parliament was adopted after making a particular change to the proposal of the respective committee, which read '... the EU should have a bigger budget than it has at present, so as to be able to take effective action' (European Parliament 1998a, 5).

12 Dullien (2012, 2013) and Palme et al. (2013) and Sutherland (2012). 
for the French Council of Economic Analysis. They propose a mechanism where each country receives a net transfer according to the difference of its unemployment and its structural level (estimated by the European Commission). The level of compensation would be $20 \%$ of workers' salaries. Every member state would pay a gross contribution equal to $20 \%$ of its payroll multiplied by its structural unemployment rate. Based on these features the system would in each year be roughly in balance and also the net receipts of every member state would in the (very) long term be zero. This would, however, depend on the details of estimating the structural unemployment rate, covered payroll etc. The balance of the system and the net position of each member state would not necessarily be fully guaranteed, which could seriously hamper the chances of agreeing on this system.

Without going into further details we should recognise the problem that the unemployment rate is not an ideal indicator of a shock as it reacts with a considerable lag to the initial adverse factor (fall in export volume or prices or aggregate income due to any reason; see also critical remarks by Allard et al. 2013, 20, and Wolff 2012, 8).

One motivation behind the proposals for an unemployment-based smoothing mechanism can be an attempt to develop, even in a limited form, a European unemployment benefit system managed by the European Commission. This would require some degree of harmonisation, which can be an aspiration for the federalist minded, but equally well an obstacle for gaining sufficient support. The latter is probably a reason why no progress has been made on this front, even though an unemployment-based smoothing mechanism was mentioned as an option both in the report of the four presidents in 2012 (Van Rompuy 2012, 11) and in the parallel blueprint of the European Commission (2012, 31-33). It no longer appeared in the report of the five presidents in June 2015 (Juncker, 2015) nor in the European Commission Communication of October 2015. This may indicate that doubts of its plausibility have mounted.

In parallel, the proponents of unemployment based schemes have improved their proposals to make them more acceptable. One addition is to agree on 'clawbacks', i.e. a country that has become a net recipient or net contributor over an extended period of time pays an additional amount or receives a special compensation (Andor, 2014, 188; Dullien, 2014, 193). The term is borrowed from the private sector where part of bonuses to top managers have been called back in cases where they have been considered unduly excessive. Precise wording for 'clawback' clauses remain open. The orientation in the present paper leads to note that referring to the origin of the term 'clawbacks' is not promising as it implies that the clause would only apply in extreme cases and in situations which went far off what was foreseen. Also, such circumstances would lead to difficult negotiations and backfire by augmenting mistrust among the partners. The difficulties in agreeing on the rules for the transfers ex ante would only be supplemented by quarrels in applying the 'clawback' clause ex post.

\section{(b) Output-based proposals}

As smoothing mechanisms aim at levelling out fluctuations in production, income or other overall indicators of economic performance, several transfer mechanism proposals are based on some of these variables. The two high-level reports in 2012 called for investigating such schemes. One prominent proposal is in Enderlein, Guttenberg and Spiess (2013; henceforth EGS), published by Notre Europe, Jacques Delors Institute (as a follow up to the Tommaso Padoa-Schioppa Group Report by Enderlein et al. 2012). Wolff (2012) presents a basically similar proposal, and Allard et al. (2013, 
19) discuss, inspired by the Padoa-Schioppa Group Report, a 'rainy-day fund' for a country hit by an adverse shock. ${ }^{13}$

The proposal by EGS (2013a and b) is relative simple. The transfer from (or to) each member state is calculated as a given fraction of its output gap minus the euro area average output gap, all variables expressed as percentages of potential output. In their baseline example they set the fraction at 0.5 .

Basically, in each year the system as a whole is in balance, except for rounding errors or other minor statistical problems. Also, over a long enough period net contributions of each member state should be close to zero, provided that the (estimate of the) output gap is zero on average over a long term. The authors present a calculation that shows that using output gap data over 1999-2014 the cumulative net balance of the system is a modest $0.2 \%$ of the euro area GDP. They also produce a calculation according to which the smoothing effect on variations of production and income is $40 \%$ if the real time output estimates would have prevailed, and still a significant $15 \%$ when the mechanism is tested with ex post data.

The mechanism studied and proposed by EGS has been criticised by the proponents of the unemployment based schemes mainly because the estimates of output gaps are uncertain, volatile and sensitive to revisions as new data comes in. The DG EMPL team showed that a mechanism based on the real time output gaps over 2002-2007 would have aggravated the cyclical disturbances (European Commission 2013a, 5-8). EGS (2013b, 29-31, 48-49) respond to this criticism by referring to the exceptionally large disturbances after 2007, and consider that the revisions of the output gap estimates should not be a reason to dismiss using output gap data for this specific purpose. Probably there is no indicator that would have fared much better before and after the bust of 2008. Yet, it is important, as also accepted by Hers and Sucker (2014), McMorrow et al. (2015) and EGS (2013a and b) that for several serious reasons, including to avoid inducing pro-cyclical fiscal policy, the output gap estimates and their use for policy design should be improved.

In section 5 we shall show how the currently available estimates can be used for designing and operating the smoothing mechanism proposed in the present paper. ${ }^{14}$

\section{A simplest possible model for redistribution and smoothing in monetary unions}

\subsection{A linear 'negative income tax schedule'}

The literature review above revealed that often the studies have failed in making a clear enough distinction between redistribution for reducing income disparities and smoothing short-term shocks that occur partly as a side effect of redistribution and partly though other mechanisms. The same

13 The 'rainy-day fund' in Allard et al. (2013) is financed (roughly) proportionally by its member states. Therefore, in practice, the financing side does not contribute to smoothing.

14 In addition to the two types of proposals for EU-wide transfer systems reviewed above, a comprehensive study by Bargain et al. (2012) should be noted. It is a study of an EU tax and transfer system which would replace one third of the national systems by an alternative system of fiscal equalisation for the EU. They use household microdata from 11 Eurozone countries. Their conclusion is that the redistributive impact would be so large that finding political support for such reforms would be difficult. Their judgement is also that, although the scheme would improve fiscal stabilisation especially in credit-constrained countries, in broad macroeconomic terms smoothing of asymmetric shocks would be disappointing. 
applies also to the difficulties in making the distinction between common and asymmetric shocks. We now clarify these issues with the help of a simple model.

The central authority collects taxes and provides transfers to the lower level entities which are at different income levels. The entities can be individuals, regions or member states in a monetary union. The basic principle is what is called 'a negative income tax', i.e. a tax schedule that levies a negative tax on low income level entities, i.e. they receive a transfer defined by their income level.

We only have transfers in the simple case, without borrowing or lending, implying that the revenue of the central government equals its expenditure. The only element in addition to the pure transfer mechanism is that there is common public expenditure (other than transfers) which is financed from a separate income tax assumed to be proportional to the taxable income of all entities. We deem this part of the model to be non-redistributive. ${ }^{15}$

The model only encompasses instantaneous flows to and from the budget of the central authority. It is explained with the help of graphs without bothering the reader with mathematics.

The first, simplest possible case encompasses a pure transfer mechanism where common public expenditure and its financing from taxes are left aside. Income before taxes (factor income) of each entity is expressed as a percentage of the average of all entities which is set at 100. The 'negative income tax' schedule is assumed to be strictly linear, which means that each entity receives a fixed transfer (i.e. pays a negative tax component) and a constant proportion of its factor income. This proportion is the marginal tax rate. In our example we set at $20 \%$.

The budget of the central authority is in balance when the constant transfer is the opposite number of average income multiplied by the marginal tax rate. The entity with zero income receives the constant transfer, in our case 20 units, and pays no tax. Thus, the 'average tax rate' is minus infinity for an entity with zero factor income and approaches the marginal tax rate for high incomes. The system transfers money to those below the average factor income level and takes a positive net tax from those above (see the Technical appendix for the graph on this case).

For putting realistic numbers on both the average and marginal tax rates we need to add common public expenditure to the system. In Figure 3.1 it is expressed as a percentage of total income and a strictly proportional income tax is collected for its financing. It is here assumed to be $20 \%$ of total factor income, requiring a proportional tax equalling $20 \%$ of factor incomes of all entities. Together with the redistributive system above the marginal tax rate is now $40 \%$.

The linear tax payment line in Figure 3.1 is positioned so that the entity at the average factor income (100) pays a tax of 20 units. The excess of the marginal tax rate over the tax rate for the proportional income tax (for financing the common expenditure) is the factor that determines the degree of progression in the 'negative income tax' system. The budget of the central authority is balanced at every instant.

15 If it were alternatively judged that some part of common expenditure, say defence or maintaining public order, benefits all individuals in equal absolute amounts, the low income earners were favoured as they contribute less to its financing as the tax is proportional to income; this could be interpreted as redistribution and incorporated into the definitions of the variables in our model here; for the purposes of the present exercise the conventional definition of regional redistribution proper is sufficient. 
Figure 3.1 'Negative income tax' for transfers and public expenditures

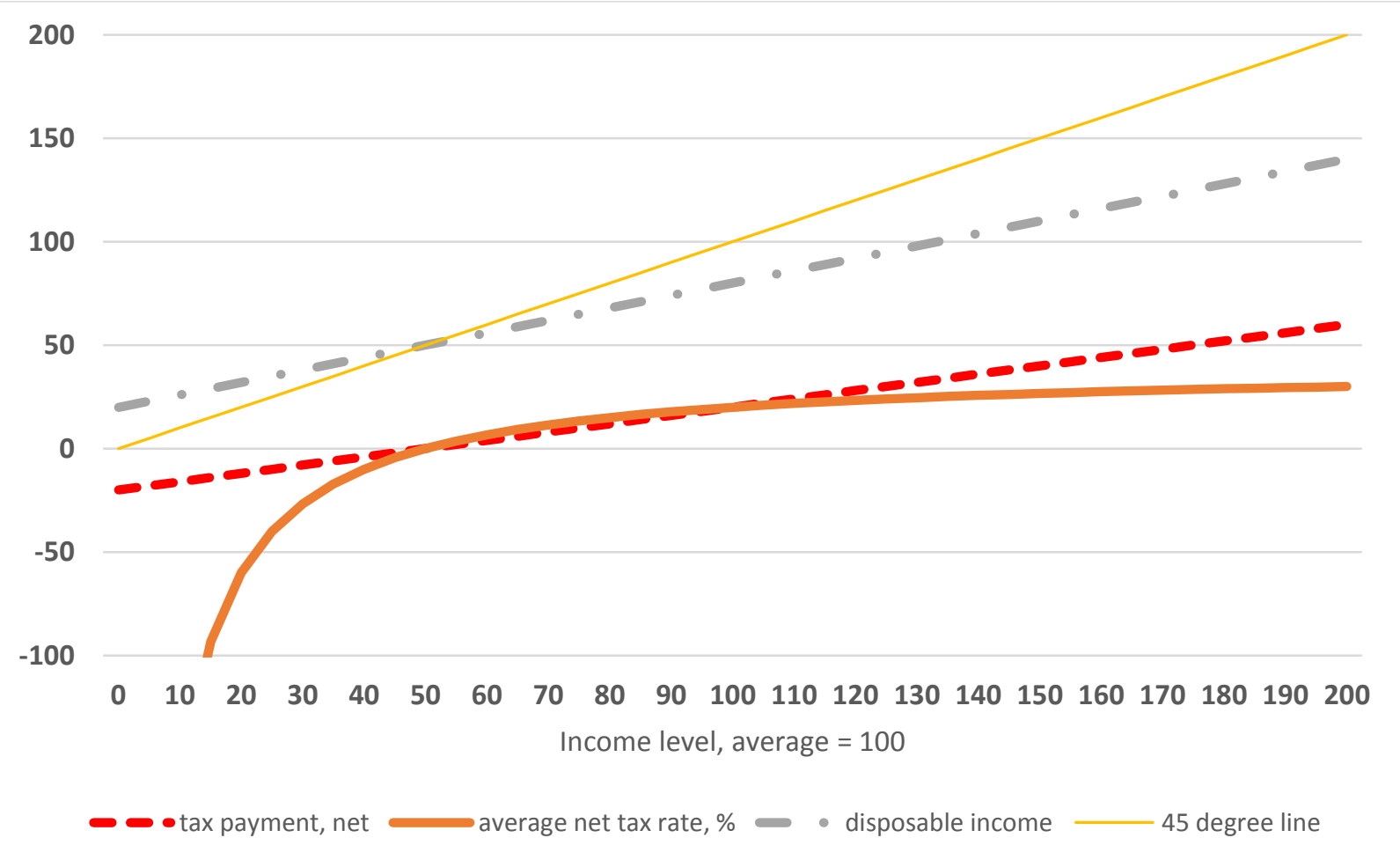

Legend: Taxable income of each economic agent on horizontal axis, average income $=100$. Tax payment and disposable income measured as percentages of average income. For explanations, see the main text.

We apply this simple model for two purposes: (1) we calculate the transfers from the high income entities to those below average income, i.e. redistribution which results from the income disparities and the slope of the 'negative income tax' schedule; (2) we observe that the marginal tax rate is the smoothing factor in the situation where an entity is hit by a shock: as its factor income is reduced, its tax payment is reduced by the amount given by the marginal tax rate, i.e. by 40 cents for one euro, while the disposable income is reduced by 60 cents. This is the same at all income levels as we assume a strictly linear tax schedule.

The shock on income can be permanent or temporary. If it is permanent we tend to regard the effect as a change in redistribution of income, while if the shock is temporary we regard it as smoothing (or risk sharing). However, it is the same factor - the 'negative income tax schedule' - that determines both of these effects and it is only the time dimension of the shock that tends to guide our terminology.

An important specification has to be made. In the previous reasoning we assumed that the shock is asymmetric, i.e. it hits only the entity in question, and that the entity is a negligible fraction of the totality, so that the shock on it does not affect the average income. If the entities are individuals of a nation, this assumption is valid. But when applying the model to regions or states in a federation or to countries in a union, the simple example above is valid only if the entity is a small enough fraction of the totality. If it represents a significant part of the total, the income loss of the entity in question affects the average income of the totality. So, for example, when applying the model to the euro zone, where the income (or production) of the largest member state makes about $30 \%$ of the total, the relative effect on this member is reduced by a coefficient of 0.7 . 


\subsection{Examples of redistribution and smoothing}

The simple model above can be used to analyse the orders of magnitude of redistribution and shock absorption in monetary unions that have been studied for assessing the viability of the euro. The idea is to use stylised data on the level of common expenditure and the marginal tax rate and calculate the redistribution implied by our simple 'negative income tax' schedule, and compare the result with real world data on transfers. If the observed redistribution in favour of low income regions is larger than implied by the model, then we conclude that there are transfers that are based on some other indicators than the income level or that they should simply be labelled as lump-sum transfers.

Table 3.1 Regional redistribution by 'negative income tax'

\section{a."United States"}

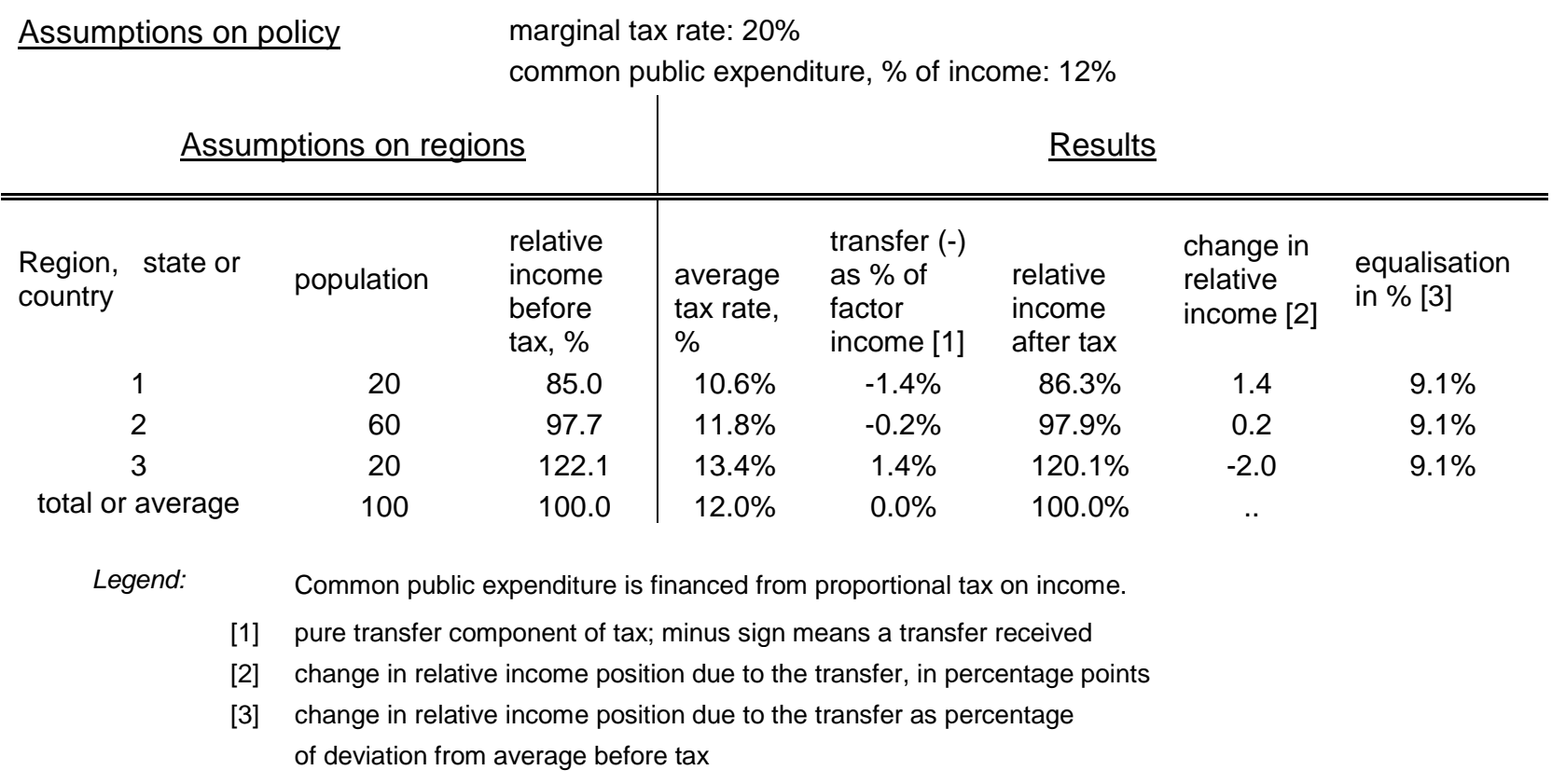

\section{b. EU Welfare state à la MacDougall}

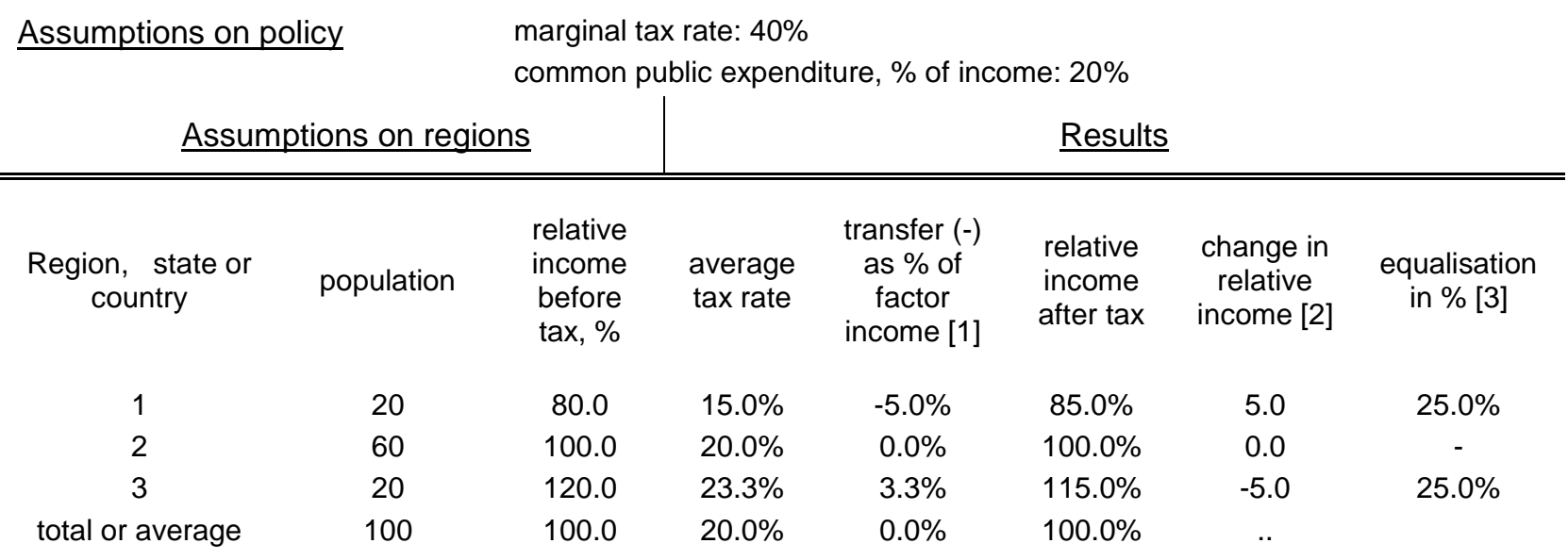


In Table 3.1 we present two simple calculations on redistribution and smoothing asymmetric shocks in cases that resemble, albeit only distantly, the main real world examples that have been objects of econometric estimates in the previous studies for assessing the viability of the euro.

In panel (a) we have the US. The rough numbers are that the states with the lowest factor income level making $20 \%$ of the population are at the level of $85 \%$ of the average, and the highest are at the level of $122 \%$ (Data from https://en.wikipedia.org/wiki/List of U.S. states by income). Common expenditure of the federal government is set at $12 \%$ of GDP. We give a round number $20 \%$ for the marginal tax rate of the 'negative tax schedule'.

The result is that the lowest income states receive a net transfer of $1.4 \%$ of their factor income, and those in the high bracket pay the same (those in the middle receive a small amount as they are a little below the average income). The last column in the table gives the proportion as to how much of the factor income disparity is compensated by the net transfer: it is $9 \%$, meaning that the lowest income level states at the level of $15 \%$ below the average receive a transfer of $1.4 \%$ of their factor income, which eliminates $9 \%$ of the disparity.

According to Poghosyan, Senhadji and Cottarelli (2015, 72, Table 2.4a) this group of states receives a net transfer of roughly $8 \%$ of their GDP. Thus, it compensates $8 / 15$, or nearly half of the factor income disparity, significantly more than estimated in the first serious study of this subject, the MacDougall Report where it was put at 28 \% (Commission of the EC 1977, 30).

Assuming for our calculation a higher marginal tax rate than the $20 \%$ used above, for example $30 \%$, does not help much. This leads to a conclusion that something important is missing from our simple picture. It could be that the net transfer system is not linear but the marginal tax rate is higher at the low and high ends of the income spectrum. This would correspondingly mean that the smoothing factor is low for the bulk of the economy located near the average income level.

Another possible reason might be more important: redistribution probably contains transfers that are not based on income levels monitored annually but on much longer-term averages or some other variables that do not correlate closely with taxable incomes. With reference to our simple model they should rather be characterised as lump-sum transfers. This is compatible with the many estimates that in the US redistribution are strong but shock absorption via the federal budget is small.

Panel (b) of Table 3.1 represents a rough picture of a reference country in the MacDougall report for a European welfare state with large solidarity transfers to the less advanced regions. The stylised facts are: the three regions represent 20,60 and 20 per cent of the population and the income levels are 80 , 100 and 120, respectively. The common public expenditure is $20 \%$ of GDP.

A 'negative income tax' with the marginal tax rate at $40 \%$ (which corresponds to various estimates for smoothing in the short term), implies that $25 \%$ of factor income disparity is levelled out, i.e. a region with a factor income level of $80 \%$ is lifted to the $85 \%$ level by the net transfer. This is less than the $40 \%$ equalisation in a sample of European countries found in the MacDougall report. Based on this we must infer that some additional transfer mechanisms are operating in addition to the simple 'negative income tax'. Importantly, this also means that this additional part of redistribution does not have the side effect of smoothing asymmetric short-term fluctuations.

The online Technical appendix presents a stylised case regarding German reunification in 1990. It is particularly interesting as it can be seen as a 'real experiment' in social and economic policies whereby a new region (former GDR) was instantly integrated to the Bundesrepublik welfare and tax 
regimes. The new region with a significantly lower income level gained large and persistent transfers. This case provides background for analysing below the EU policies regarding enlargement to the former socialist countries.

The main outcome from the three cases is that in the real world there are other transfers that come on top of the redistribution stemming from the schemes under the 'negative income tax'. This implies that if all the ongoing redistribution were re-arranged so that it all results from the one and uniform schedule based on the recorded income levels, say, on annual basis, then the marginal tax parameter would be higher than observed. This implies that the degree of smoothing of changes in relative income levels would be significantly increased, as the result of maximising the smoothing effect for a given degree of redistribution.

The online Technical appendix also presents an illustration of how well the key recommendations in the MacDougall Report fit together. Our rough calculation shows that it is difficult to achieve the degree of redistribution called for by the MacDougall group with the common budget of 5-7\% of GDP which they considered as a minimum for supporting a European monetary union.

In addition, we shall see in the next section that not even the pre-federal stage budget of $2-2 \frac{1}{2} \%$ of GDP recommended by the MacDougall group to start preparing the monetary union is politically realistic in the EU.

\section{The EU budget viewed from the angle of redistribution and smoothing of shocks}

\subsection{Agenda 2000 principles}

In parallel with preparations for the euro, the EU was occupied with an equally challenging task of the accession of the former socialist counties. The first milestone was adoption of the Copenhagen criteria in 1993, and the second was the Agenda 2000 report of the European Commission in 1997.

Agenda 2000 was based on the conclusions of the heads of state and government in Edinburgh in 1992 implementing the agreements in Maastricht in 1991. The ceiling of the EU budget was firmly set at $1.27 \%$ of EU GNP, and the allocations to regional and structural funds at most $0.46 \%$ of the EU GNP. These restrictions were agreed to be valid even after 1999 which was the end of the Edinburgh financial perspective. Agenda 2000 set also the ceiling that 'at all events, total transfers from the Structural Funds and the Cohesion Fund to a present or future Member State should not exceed 4\% of its GDP'. One operational restriction for achieving this was not to allocate Objective 1 support to areas at income levels above $75 \%$ of the enlarged EU on average (European Commission 1997, 21-22).

Interestingly, the numbers for maximal transfers in the EU are roughly one tenth of the ones that resulted from the previous 'enlargement', the German reunification, which are estimated to have been persistently $35 \%$ of the GDP of the Eastern recipient Länder and about $4 \%$ of the Western contributors. ${ }^{16}$

The significant transfers in Germany probably were one reason why the restrictive principles for the eastern enlargement of the EU had to be stated firmly, as otherwise the suspicion that the cost will

16 https://en.wikipedia.org/wiki/Economic_history_of_the_German_reunification referring to Ghaussy and Schäfer, The Economics of German Unification (1993) p 41. 
explode would have prevented enlargement from happening. In any case, comparison of the numbers in Agenda 2000 and those of the German unification illustrates that accepted solidarity across the EU member states is only a small fraction of the observed degree within the member states - most other European welfare states are not very different from Germany in this respect.

\subsection{The current EU budget}

The EU budget is today $1.1 \%$ of Gross national income (GNI) and the redistributive flows have followed the guidelines set in Agenda 2000 as endorsed in the accession treaties and elsewhere.

Figure 4.1 shows net contribution to the EU budget of each member state over the period 2008-2013 as a percentage of their income (GNI PPS), ranked by their relative per capita income level (averages over 2008-2014). In the Technical appendix we report separately their receipts from the regional and structural funds and from EU agricultural policy.

According to Figure 4.1 the less advanced member states have recently received up to four per cent of their GNI, with Lithuania at $4.5 \%$. Bulgaria and Romania received relatively less, which obviously results from their accession only in 2007 so that they did not yet fully benefit from regional fund support in 2008-2013.

Figure 4.1 Relative income level and net contribution to EU budget by member state, \% of GNI

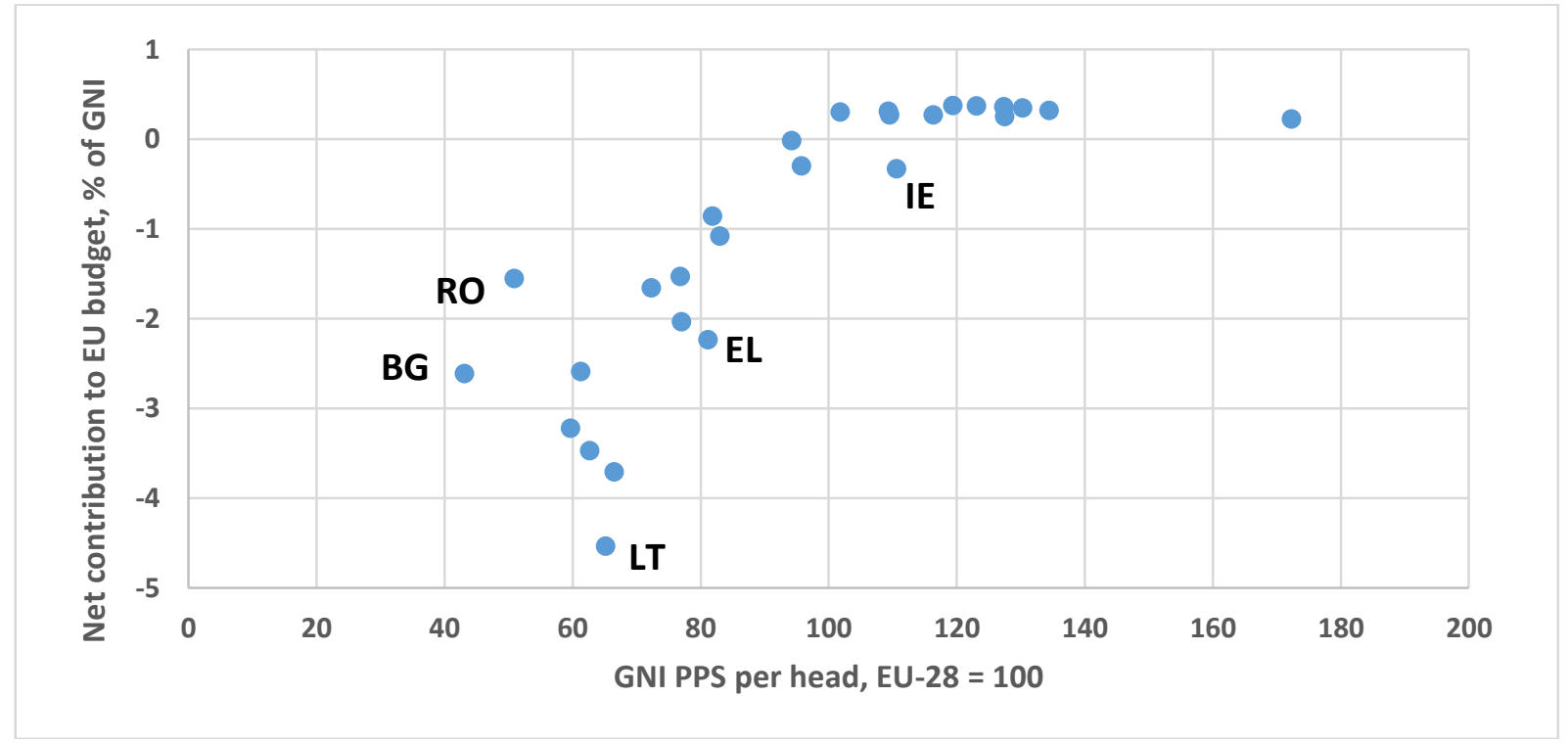

Legend: relative income levels: averages in 2008-2014 in PPS; contribution to and revenue from EU budget: averages in 2008-2013. GNI is gross national income. Some particular member states marked, see Abbreviations at the end. All member states can be traced with the help of the data in the Technical appendix.

Sources: European Commission: AMECO and Financial Report 2013.

\subsection{Transforming solidarity transfers in the EU for smoothing shocks}

Regional and structural policies for equalising income disparities have developed a heavy machinery, including extensive programming for the upcoming seven year period. Being based on past data the financial flows do not react to short-term changes in the economies, which means that they barely have any smoothing effect on short-term shocks, asymmetric or common. 
For illustrating the possible link between redistribution and smoothing we construct a clear-cut alternative for redistribution, based on a 'negative income tax' analogy. Expenditure for common tasks from the EU budget is quite small, for example spending on administration and the research framework programme are only $0.07 \%$ of EU GNI each; thus, common expenditure is so small that it can be left out and we only focus on the pure transfers across the member states.

We construct a hypothetical transfer mechanism based on the income per capita levels, measured as GNI per capita in PPS. For the 'negative income tax' schedule the marginal tax rate is the only parameter to be determined. We set it at $5 \%$ in Figure 4.2. The only additional element to the pure logic of the scheme is that the net revenue is capped at $5 \%$ of GNI for Bulgaria, which would have received $6.6 \%$ of its GNI (based on its relative income level of $43 \%$ of the EU-28 average), and the net contribution of Luxembourg is capped at $2 \%$ of its GNI (without capping it would have been 2.1 $\%)$. These minor modifications are made to point out that possible other calculations with a higher marginal tax would require similar restrictive modifications to eliminate the extreme cases. Capping naturally means that the system is not in exact balance, but the deviation with the two adjustments above is negligible. Capping also means that the smoothing effect on the capped countries is reduced.

The mechanism would systematically reduce the income disparities as was called for in the MacDougall report, although only by a fraction, under the restrictions endorsed in Agenda 2000. It would increase the net receipts of the least advanced member states, but by coincidence, the net receipts of the 16 member states below the EU-28 average per capita income make $0.47 \%$ of EU GNI, almost exactly the $0.46 \%$ ceiling set in Agenda 2000.

Figure 4.2 Relative income level and net contribution to EU budget by member state according to simple 'negative net contribution' formula, \% of GNI in PPS

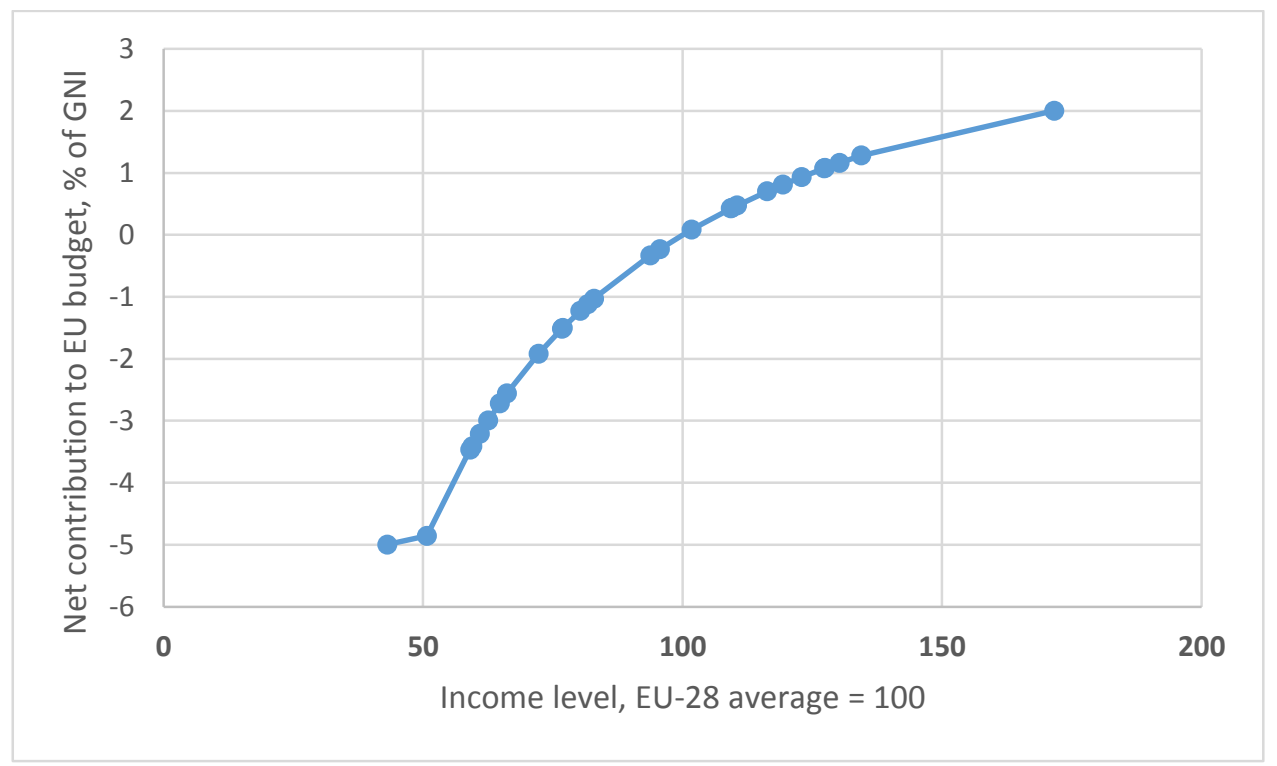

Legend: EU member states by relative income level, EU-28 = 100, averages 2008-2014.

Despite the obvious advantages of tying the regional and structural transfers in the EU tightly to income disparities, such an overhaul of those policies will not easily happen. These policies have developed in a highly politicised processes with strong vested interests. Our illustration also contains the expenditures for agriculture. Merging them to generalised transfers would require transferring a large part of agricultural expenditures to the member states (to be expended under EU regulations regarding competition and state aid policies; the national expenditures for agriculture are at the 
moment about $15 \%$ of those from the EU budget ${ }^{17}$ ). Renationalising agricultural expenditure would be so revolutionary that it is difficult to regard it realistic even if it would bring a clear advantage by eliminating the need for the UK correction and the related reductions to contributions from the Netherlands and Sweden. These items always pose difficulties in the negotiations on the EU budget framework and certainly do not help building trust.

\subsection{Summary of smoothing induced by redistribution}

In federations and unitary states significant central budgets normally redistribute income according to income levels - progressive income tax and various transfers do this. To the extent the taxes and transfers are based on income data that is observed annually, the transfers also smooth asymmetric shocks as their side effect. Our rough numbers in section 3 indicate that in the US half of the redistribution has this side effect while the other half is more rigidly tied to income levels over the longer term or they are otherwise based on indicators that do not correlate with short-term fluctuations.

The conclusion from the hypothetical exercise regarding the EU is that the acceptable degree of redistribution would support smoothing of at most $5 \%$ of asymmetric changes, and even this would be achieved only in the politically unrealistic case that all transfers are arranged under the single redistribution scheme. Therefore, the firm conclusion is that practically no smoothing can be achieved as a side effect of redistribution.

Given this conclusion we now turn to the most recent proposals for mechanisms that aim at smoothing asymmetric shocks without generating permanent redistribution and present a novel proposal which removes all suspicion of potential redistribution.

\section{A proposal for a smoothing mechanism strictly forestalling redistribution}

\subsection{A mechanism based on relative output gaps}

As explained above, EGS (2013a and 2013b) propose a mechanism where the transfers between the euro area member states are determined by the deviation of their output gap from the euro area average. The authors set the transfer relative to the GDP of each country as half of the output gap difference. A similar proposal is also presented by Wolff (2012).

By construction, such a mechanism serves its purpose and should be roughly in balance and the net contributions of each member state can be expected to be close to zero over a longer term. Another clear advantage compared with several other proposals is that the mechanism is symmetric in the meaning that the transfers not only dampen the adverse shocks but the country pays to the system when its relative output gap is positive. It also smoothens fluctuations in all the participating countries equally regardless of their relative income level.

Despite its positive features the proposal by ESG (2013a and b), or on any other smoothing proposal for that matter, has not received decisive support. This probably results from the suspicion that redistribution may not be fully excluded, especially if the economies are hit by unusually large shocks like the one in 2008. For eliminating this we present a modified proposal which fully removes

17 Source for national expenditures: European Commission (2013b, 128). 
potential redistribution. This is accomplished by a rule that over the medium term the balance of net transfers of all member states will be set to zero by an ex post clearing mechanism.

The novelty in the present proposal is a simple rule: the mechanism would be run in seven-year periods, calculating the balance of each member state at the end of each period and the negative balance of any country will be paid in or a positive one reimbursed in equal annual instalments during the next seven-year period. Such a simple rule removes in one stroke the suspicion of ending up in permanent redistribution even in very exceptional circumstances.

This overarching rule also alleviates the problem with possible biases in the output gap estimates and their revisions for any other reasons. Under all occurrences the net balance of each member state will be zero in the long term. The transfers can simply be based on real time estimates that represent the best knowledge at each point in time (improving the real time output gap estimates and their revisions for various other purposes is a separate matter).

Three major features of the new proposal are as follows:

The first one is to determine the proportion of the relative output gap (difference to the euro area average) that determines the transfer. EGS (2013a and 2013b) propose 0.5, i.e. the transfer (relative to GNI or GDP) is equal to half of the percentage output gap difference (Wolff 2012 leaves this open, proposing also that only relatively large output gaps would be tackled, the smaller ones being left to be dealt with by each member state). EGS $(2013 b, 55)$ show that according to their model 0.5 is a good compromise between effective smoothing and limited net payments. Here, we do not have a similar trade-off as net payments, ex post, will be zero anyway, but 0.5 can be regarded acceptable as it should give a significant effect without attempting to eliminate the differences altogether. ${ }^{18}$

Secondly, the review period could be anything between five and ten years. Seven is used here as it is a number that has fared well over thousands of years in tales about cycles. It is also the horizon of the EU multiannual budgets, although the proposed mechanism should rather be run outside it. The period should be long enough to cover normal cycles and short enough to assure that the decision makers do not forget that balancing the net transfers is an intrinsic part of the system.

Thirdly, the transfers are here proposed to be based on relative output gaps while some other cyclical variables could also be considered. GDP growth rates are another obvious alternative, but the issue is that after a boom the growth rate already turns lower when the level of production is still at a high level, and conversely after a recession - this may lead to suboptimal timing of transfers, which is indeed the reason why output gaps are estimated and used. Figure TA5.1 in the Technical appendix illustrates the euro area averages for the two indicators in 1995-2016. However, further thinking on this matter should not be excluded. For example, under regular cycles the relative growth rate can be a useful indicator as it is a forward looking indicator. If we are not sure whether one single indicator is best, composite indicators could be considered, as also mentioned by EGS (2013b).

18 Gros (2014) presents a radically different view and criticises the other proposals (by Allard et al. 2013, Dullien 2013, and EGS 2013) for smoothing only a fraction of the shocks. He proposes an application of an insurance mechanism with a deductible: for example, no compensation if the loss is less than $1 \%$ of GDP but everything above the $1 \%$ would be offset. This is hardly economically efficient nor politically realistic for the EU due to the issues with moral hazard and the consequent risk and suspicion of unacceptable redistribution. Also, his proposal, like many others, tackles only negative effects but does not moderate booms. 
In addition, the following more detailed questions require attention:

1. Should interest be paid on the balance of each member state in the mechanism? Probably so, in order to eliminate even this tiny element favouring a member state that starts with a negative balance.

2. Should the transaction and balances in the mechanism be treated as transfers or pure financial transactions (like deposits and borrowing)? Treating them as transfers would remove part of the cyclical (or short-term) component from the government budget balance. Using the structurally adjusted government balance in various other places in EU fiscal rules serves the same purpose. Here, the proposed mechanism would affect directly the measured 'government deficit'. Modifying the famous $3 \%$ of GDP ceiling for deficits, even if it is commonly considered to induce harmful rigidity, has not been accepted politically. Inducing flexibility via the proposed transfer mechanism would thus be an advantage. As the net transfers would always be unknown and depend on the economic development even in other countries, the statisticians should be able to accept that these transactions indeed are transfers and not deposits and borrowing. If they did not accept this interpretation, the solution should be that, for attaining the economically sensible purpose of the mechanism, a specific adjustment would be made to the official government budget balance data when used for the excessive deficit procedure and the other procedures under the SGP.

3. As a detail but important for the largest member states, the size of the member state could be taken into account when calculating its relative output gap by replacing the euro area average by the average of the other members.

4. We are here considering the euro area and not the EU as the whole as the issue here is adjustment in the monetary union. However, as Denmark is anchoring the krona to the euro it should be allowed to join the mechanism, perhaps voluntarily.

For an illustration of the proposed mechanism Figure 5.1 shows the European Commission's real time output gap data for the 12 euro area members (EA-12, original 11 and Greece) for 2002-2016, and the ex post estimates for 1996-2001 published in 2002 when the current method for output gap estimates was adopted (in 2004 for Luxembourg). The figures for 2016 are the forecasts of autumn 2015.

The time period is chosen to cover three seven-year periods. It starts three years earlier than the euro was introduced. The calculations do not aim at estimating the effects of the proposed system, even less the effects of adopting the euro. They simply give the hypothetical transfers induced by the proposed mechanism for countries which would have had the relative output gaps appearing in the data. Most likely, if the mechanism had been operating, the relative output gaps would have been smaller. Leaving this for further research the preliminary view could be that the estimates by EGS (2013b) referred to above are roughly valid for our case, although not exactly as our rule of clearing the cumulative balances from the previous seven-year period obviously plays an additional role. We also leave aside here the philosophical and methodological issue of estimating the real world effects as the transfers need to be based on real time data while as time passes any measure appears in a new light. We are basically presenting a mechanism that is better than nothing and argue that it does not do any harm. 
Figure 5.1 Output gaps of EU-12 members in 1996-2016, real time estimates

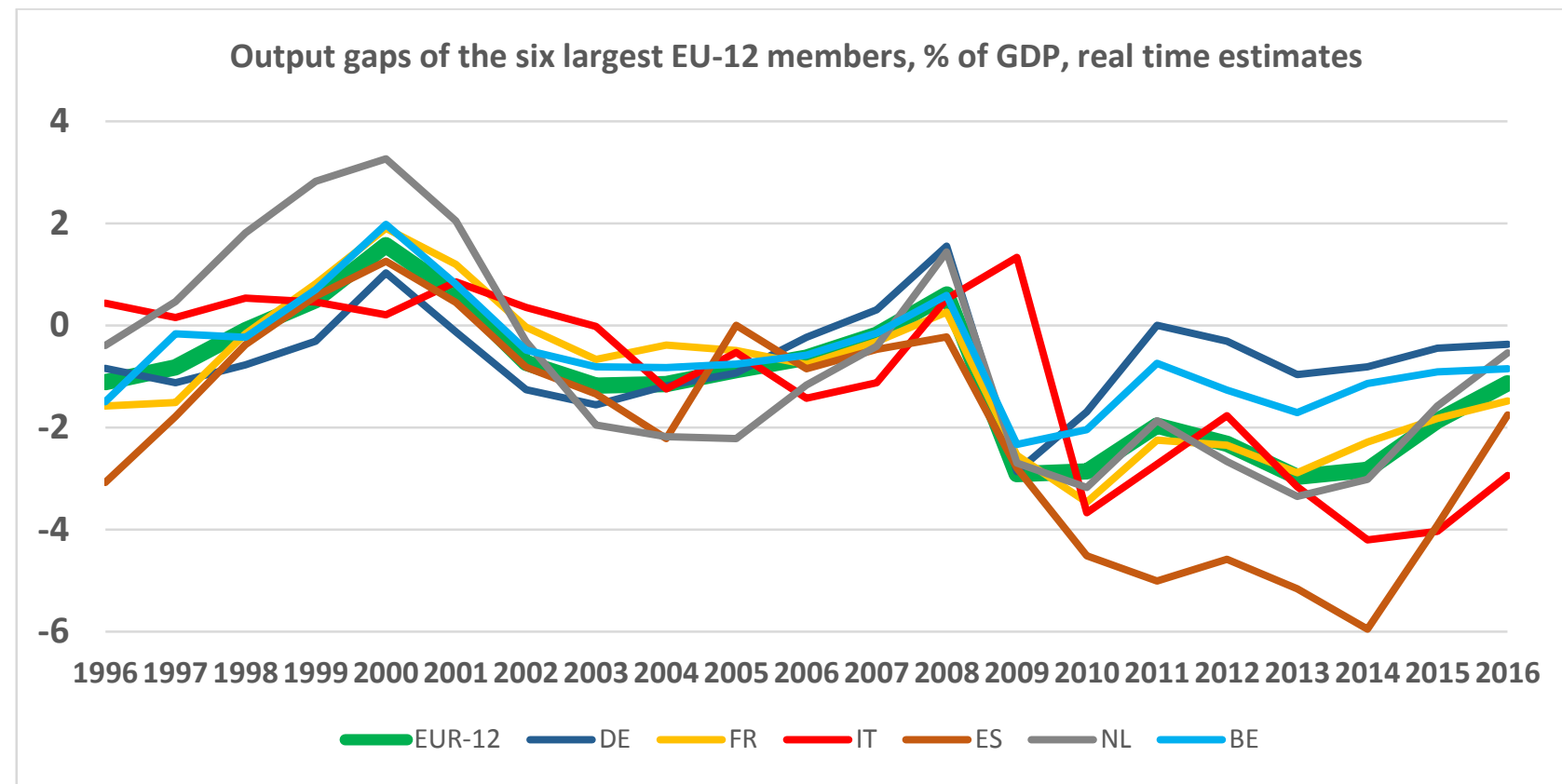

Output gaps of the six smallest EU-12 members, \% of GDP, real time estimates

10

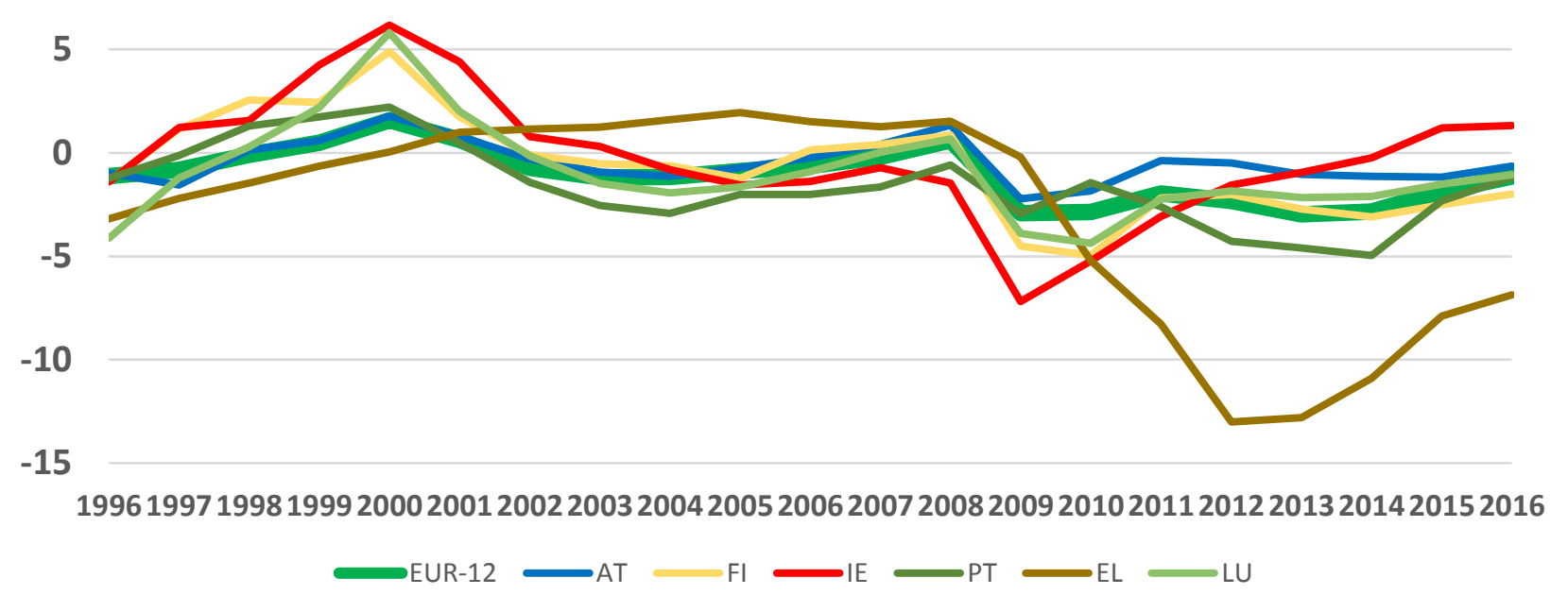

Legend: member states in the order of size, GDP in 2015; for identification see Abbreviations at the end. Source: European Commission.

Figure 5.2 shows the transfers for the second and third seven-year periods for four selected EA-12 members, the two largest, and two crisis countries, Spain and Greece. The graphs report both the component based on the relative output gap estimated in real time, which is the desired smoothing factor, and the correction component clearing the cumulative balance from the previous seven-year period. 
Figure 5.2 The transfers implied by the proposed mechanism for four EUR-12 members

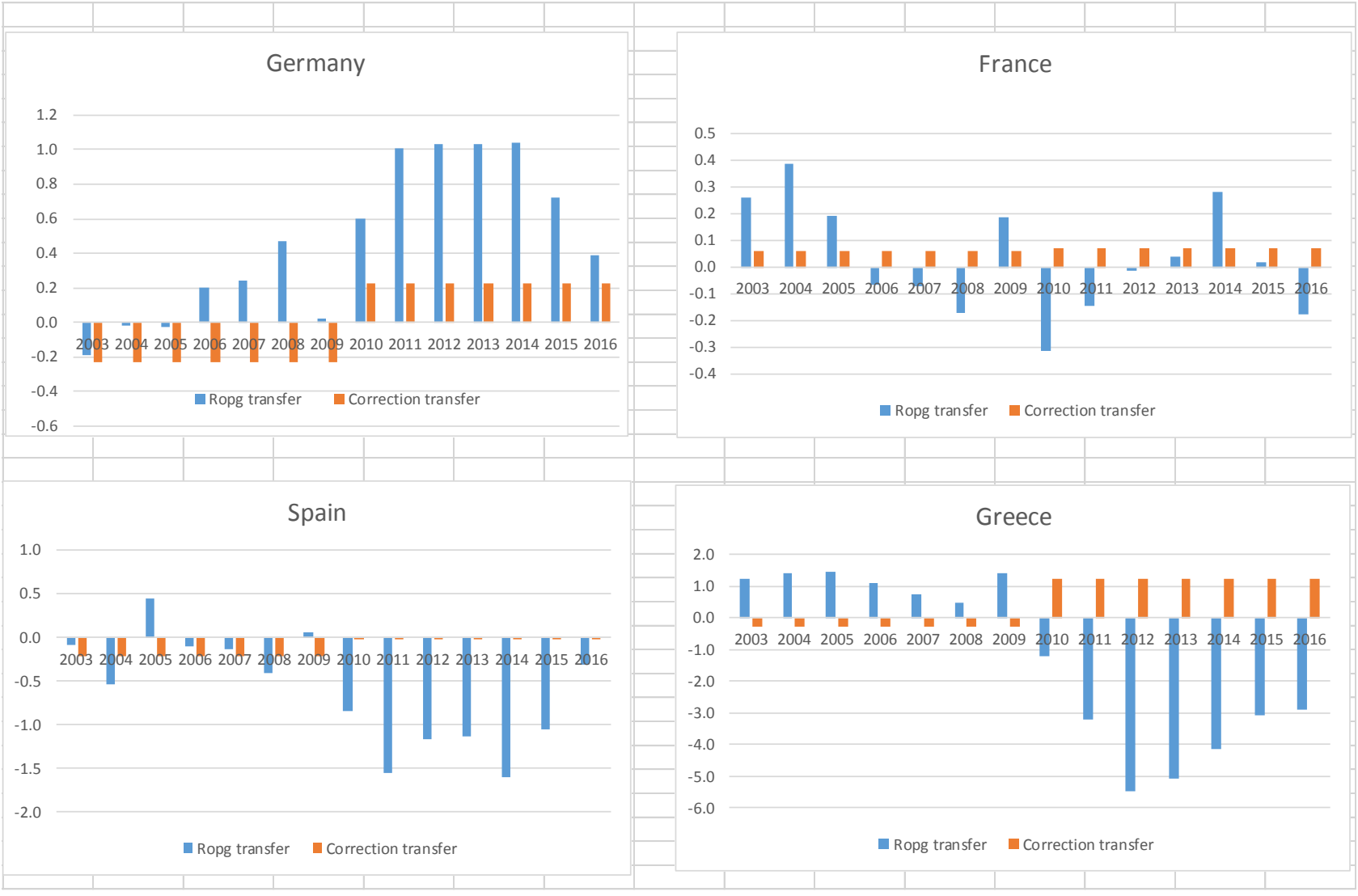

Legend: 'Ropg transfer' is the annual transfer based on the relative output gap in each year. 'Correction transfer' is the constant payment or revenue over the seven years covering the cumulative transfer received or paid in the previous seven-year period.

Ropg payment to the mechanism has + sign, and revenue from it has - sign; the graphs show the Ropg transfer based on the real time relative output gap for each country; the Correction transfer has + sign when the country receives a transfer for recovering a positive cumulative Ropg payment in the previous 7-year period, and vice versa; when the bars are on opposite sides of zero, the correction component amplifies the effect of the first component; when they are on the same side, the correction neutralises it partly or fully.

For the four countries in Figure 5.2 the mechanism works well most of the time: the correction factor most often amplifies the intended smoothing effect. The results for the other eight members in EUR12 are presented in the Technical appendix, Figure TA.5.2. In the whole data for EA-12 we have 12 x $14=168$ observations. In most cases the correction factor amplifies the intended smoothing effect, but in 66 it eliminates it partly or fully. However, in only 30 of those cases is the correction factor larger than $0.25 \%$ of the GDP, and none of them concern the four largest members. In 22 of the adverse cases the correction factor eliminates the intended effect fully, and 13 of these cases concern two counties, Finland and the Netherlands. These two happen to be exceptional also in other respects that may affect their relative output gaps: their pension systems are partially funded (the reserves recorded in the general government accounts in FI and in the private sector in NED), which may have affected their cyclical dynamics and enhances their capacity to borrow from the international financial markets. 
The system would have been virtually balanced throughout the 21 -year period - this follows from its construction as the deviations from zero at each point in time follow only from the minor inconsistencies in the data, merely aggregation biases and possible rounding errors. The largest annual imbalance is $0.4 \%$ of euro area GDP in 2009. Over the whole period the cumulative balance is 0.4 $\%$ of annual GDP.

While all other cumulative balances to be cleared afterwards do not stand out as especially worrying, Greece appears as a special case that would test the viability of the proposed system. At the end of our illustrative data, after the hard times of 2009-2016, its cumulative negative balance is roughly 25 $\%$ of its annual GDP. It can be asked whether its possible failure to pay this back would jeopardise the proposed system. Probably not too badly, as the Greek case is so exceptional: the balance of 25 $\%$ of GDP is only a small fraction of the Greek public debt, in 2015 about $195 \%$ of its GDP. The euro area partners have been compelled to disburse financial assistance to Greece, so the risk with the $25 \%$ would be only part of larger issues.

In general, would all countries pay back what they received when doing relatively badly? Part of the answer is that if they still do badly, according to the mechanism, new transfers to them would be reduced correspondingly; true, reimbursing the negative balance would only be postponed, but not disbursed. If the country were already doing relatively well, it would have to pay back. Making this commitment legally binding is work for the lawyers, to be clarified in the context of legal obligations in general (it could be a minor component in setting the rules for the proposed insolvency procedure for sovereigns as proposed by Fuest, Heinemann and Schröder, 2016; Dolls et al. 2016).

Our results on the functioning of the proposed mechanism should be taken only as an illustration as past data would not show its effects. Also, we should note that the seven-year periods in the illustration are arbitrary and other sets of seven-year periods would give somewhat different results. However, as the turn of the year 2008/2009 is the dividing line between our second and third period and it happens to have been almost exactly the start of an unusually deep recession, the illustration exposes our proposal to a demanding test.

\subsection{Are there better ways to achieve the same targets?}

Any new proposal has to be assessed by posing two questions: is the issue to be addressed serious enough to desire attention, and if so, can the same targets be achieved by other means, possibly at lower cost and effort.

First of all, we can safely exclude a large common budget á la MacDougall report of 1977 that would both redistribute income in favour of less advanced member states and have the automatic side effect of smoothing asymmetric shocks.

Next, in the literature review we found the view that integration of private bond and equity markets would in due course take care of risk sharing; enhancing this has been seen as a way to go, without need to establish smoothing mechanism across the governments. Still recently the Communication from the European Commission $(2015,14)$ in October 2015 broadly counts on this view.

However, the emergence of such an integrated market would probably take decades, and we may not have so much time to waste. We have seen that quite opposite developments took place in the financial markets in the first 15 years of the euro and what came about was not smooth sailing. For example, Baldwin and Giavazzi $(2015,57)$ and Lane $(2015,129-130)$ note that the increased scale of intraeuro-area cross-border integration of banking and bond markets was partly accountable for the boom- 
bust cycle. The capital flows tended to feed non-tradable sectors on the periphery and financial integration did not play as a smoothing device when the crisis hit. Quite the opposite, crisis countries suffered sudden stops.

A more specific argument: risk sharing through private financial markets as is prevalent in the US will not be easily reached as private saving for pensions is lower in Europe, and additionally, the existing pension fund reserves invested internationally partly go outside the euro area (most of the exchange rate risk being probably covered by accompanying contracts). Thus, this part of their investments does not function as risk sharing across the euro area.

Regarding the various proposals for specific smoothing mechanisms we noted above that they are often quite limited. They often tackle only adverse effects and beyond some threshold, the underlying argument being that the cost should be kept limited so that they would have any chance to be politically accepted. However, this also means that their effects would remain meagre.

As these various options seem politically unacceptable, unrealistic otherwise or inefficient we are left with the basic questions regarding flexibility in the government budgets, notably budget deficits, known also as the credit channel.

\section{Could government budgets be made more flexible?}

As noted above, Allard et al. $(2013,14-15)$ and others have observed that rather than contributing to smoothing shocks (common and asymmetric) the government budgets became pro-cyclical under the euro. So, is it possible and realistic that this state of affairs could be significantly improved? We should note here that the shocks or cycles to be tackled can be common or idiosyncratic, but this distinction is not relevant here as most often any rule or measure that would help with euro area common shocks would also dampen the asymmetric ones.

In principle, this is possible. The general government budgets in the member states are large and the automatic stabilisers could significantly dampen the shocks. However, this would require that all parties can trust that sound public finances prevail in all countries, and that identifying 'gross errors' in government budgets, as prescribed as the purpose of the EDP in the Maastricht Treaty were sufficient. This would mean that the famous ceilings, $3 \%$ of GDP for deficit and $60 \%$ in the Maastricht Treaty would be applied as 'reference values' as they are named and not as restrictions for short and medium term policies, while judging 'sound public finances' on the basis of long-term sustainability. This would then allow the built-in stabilisers in government budgets to operate fully and, if deemed necessary, be supplemented by discretionary action in severe recessions and booms.

Implementing these principles requires accurate measures for neutral (cyclically adjusted) government balances and a sufficiently clear framework to identify the underlying long-term trends in public expenditures and, equally importantly, shifts in those trends induced by policies that affect those expenditures. The short and medium terms targets for government deficit and debt would then be a combination of the cyclical component and the underlying long-term trends, including shifts in them. These trends would be affected by population ageing, various economic factors globally, the policy parameters for the pension system other ageing related expenditures, and the changes in those policies. Analysing alternative options for policies, including intergenerational fairness, would be an intrinsic part of designing policies, all the time under the constraint that long-term sustainability of public finances will be assured. 
This type of framework makes common sense, but it is more easily said than done. Elementary work has taken place but the results remain meagre due to several obstacles that should be identified.

The importance of assuring long-term sustainability was indeed recognised right at the start of the euro in 1999 and major joint work of the European Commission and the member states on projecting pressures caused by population ageing was started. However, in 2009 the attempt to derive mediumterm targets from the long-term projections for expenditures failed to produce useful operational results. This is still the case, even aggravated by the current crisis. One reason for this is that the 'sustainability gap' calculations are too narrow to genuinely bring to the table the relevant policy options and their time dimension. Sustainable financing of pension and other ageing-related expenditures requires several policy measures, including increasing retirement age and adjusting tax rates. Most of these measures genuinely belong to the sole competence of the member states. This was even made a stronger restriction in a change to the EU Treaty in Nice in 2000, which explicitly restricts the competence of the EU in defining 'the fundamental principles of their social security systems' (TFEU 153: 2 and 4). The public finance institutions, especially those responsible for population-ageing related expenditures differ too much across the member states to make it possible to define rules that would at the same time be sufficiently accurate and operationally simple for being efficiently monitored jointly by the member states and the European Commission (Beetsma and Oksanen, 2008; Oksanen 2013).

In addition, we should note a number of other issues with assessing and monitoring public finances, all related to long-term sustainability. Even if government investment and 'other relevant factors' are mentioned in the Treaty article on the EDP, no clearly applicable criteria have been developed, including failure to make a distinction between public consumption and investment in setting the targets for correcting excessive deficits. This often triggers criticism for curtailing public investment to the detriment of future growth, for example currently when the rate of interest on public debt is low and excess capacity is available. This criticism also applies to investment in education, which due to the accounting conventions mostly enters as public consumption. Also, 'government debt' became to mean gross debt while governments in some member states hold significant amount of financial assets, notably through their partially funded pension systems that belong to the general government sector.

Another most striking example of the deficiency of accounting for government deficit and debt is treatment of mandatory fully funded second pillar pension systems. As they are classified as being part of the private sector in the national accounts, their surplus and assets do not enter in government accounts in spite of being an intrinsic part of public policy and genuinely supplementing the first pillar pensions appearing in the government accounts. This matter became acute in 2004 as some of the new member states had significant second pillars. Even if quite well-defined solutions for making accounting for the purposes of the EDP were available (Beetsma and Oksanen 2008, 568-9; Oksanen 2013, 226-8), the modifications to the SGP rules only give limited short-term leeway when shifts between the first and second pillar take place. The problems with accounting and measurement have partially led to reversals of pension reforms in some countries for improving the numbers for government deficit, especially under the current crisis when the deficit targets became hard to attain (Bielawska, Chłoń-Domińczak and Stańko 2015, 9, 85-91). This certainly never was the purpose of the EDP/SGP rules, but modifying them even for this relatively obvious flaw has turned out to be exceedingly difficult, obviously, again, for the suspicion that it would open the way for weakening fiscal discipline in general. 
One more topic is mutualisation of public debt for which various proposals have been presented (Bofinger 2016, 232-234, 237). Some of them are motivated by providing secure financial assets for monetary policy operations and some for mutualisation of the existing debts in order to facilitate a new start for the euro area. One of the main issues, often not fully acknowledged, is that a change in public debt is by definition equal to the change in government expenditure and revenue (apart from stock-flow adjustment). This means that main function of the centralised debt pool would be to channel the funds to the euro area governments. Fighting on sharing the borrowed funds between the governments would intensify, which would not enhance building trust. If this led to smaller deviations from balanced budgets overall for the euro area and for individual members, fiscal policy could become even more pro-cyclical than hitherto. ${ }^{19}$

Apart from this general comment the proposal by De Grauwe and Ji (2016) prompts attention to more specific aspects of mutual debt. They observe that the business cycles in the euro area have been relatively closely synchronised, and if there was asymmetry it was merely in the amplitudes. This is a valid observation and it leads the authors to emphasise the need for euro area wide stabilisation rather than worrying about the asymmetries. However again here, this is not decisive as their proposal would also operate under asymmetric shocks.

As they consider that a budgetary union in which a significant part of national taxation and spending is transferred to a European government and parliament is unrealistic, they make a more moderate proposal: the current European Stability Mechanism (ESM) should be extended to become a centrally operated euro area stabilisation fund which would buy national government bonds and issue an equivalent amount of mutually guaranteed bonds, up to $60 \%$ of euro area GDP. In order to avoid a net accumulation of mutual debt over the business cycle, the fund would only be allowed to lend to governments corresponding to the cyclical component of their budgets. They admit that computing reliable structural government balances is a demanding task (De Grauwe and Ji 2016, 143-145, 148).

Thus, under their proposal all the issues with defining the cyclical component of deficits and the necessity of assuring sustainability of public finances in each and every country would encounter the issues discussed above. It therefore follows that if these issues are satisfactorily solved, then there would be no need to mutualise public debts but the government budgets could be flexible enough to dampen the shocks and make the proposal by De Grauwe and Ji (2016) unnecessary.

Last but not least: also their moderate proposal would probably require changes to the EU Treaty (like also most other proposals in the same CEPR volume, see Baldwin and Giavazzi 2016, 26). This should be one dividing line when the reform proposals are seriously contemplated. Reform proposals that would require change in the EU Treaty but are not necessary or decisive tend to reinforce the extreme positions: one extreme says that a full fiscal union is necessary for the survival of the euro, and the other agrees to this and wants the euro be dissolved as they do not accept a federal EU (Mervyn King gave ammunition to this: "the eurozone is doomed", The Telegraph 28.2.2016).

19 Some mutual public debt could enhance liquidity of the markets and provide a neutral instruments for the open market operations of the ECB. For this, more limited amounts could suffice. The European Investment Bank already issues such debt, amounting to $3 \%$ of EU GDP; this is vastly greater than the debt issued by the European Stability Mechanism (ESM) which is $0.4 \%$ of EU GDP. 


\section{Further centralising of decision making?}

The various difficulties clearly show that the current rules are too simple and should be implemented with reason, but at the same time mistrust prevails and the member states suspect that giving more flexibility could be misused. This has led to creation of new centralised surveillance procedures, accompanied by various soft and hard ways to influence government finances. However, many experts consider that the bureaucratic machinery of new exercises (the European Semester and the Macroeconomic Imbalance Procedure) that supplements the EDP/SGP has become incomprehensible even for the insiders and are simply judged not to work (Wyplosz 2015, 201; Eichengreen and Wyplosz 2016a, 40; Pisani-Ferry 2016, 78; Bofinger 2016, 237).

The June 2015 report of the five presidents seems to be taking the procedures to further heights. In discussing the possible proposals (at stage 2 after 2017) for cushioning large shocks it takes the view that legally binding measures for what is called 'convergence' would be a condition for each euro area member state to participate in a smoothing mechanism, and that the member states would have to accept 'further sharing of sovereignty' (Juncker 2015, 5, 14). The risk is that the new complex procedures would only lead to new disputes and greater mistrust.

In this context, questions arise regarding the central authority to manage the new tasks. According to views from Germany and the Netherlands the centralised body to be given new powers is not the European Commission but a new body is needed (Financial Times 2015). Signalling mistrust seems to be an integral part in designing new institutions and procedures.

\section{Conclusion from considering alternative reform options}

The previous survey of various reform proposals leads to the conclusion that it is very difficult to establish procedures for monitoring sustainability of public finances in a way that could be trusted by all participants. Therefore, it is difficult to attain more short-term flexibility in public finances than hitherto. We should recognise that this is not only caused by the underlying mistrust but the reason is also that the task of defining long-term sustainability and motoring its attainment is a genuinely difficult task, not to be easily accomplished jointly by a large number of governments and several EU institutions. In the current conjuncture public finances are even weaker than before the crisis and it will take quite some time to improve them. The danger is that flexibility may decrease even further and fiscal policy turn more pro-cyclical.

This conclusion implies that no such mechanisms are foreseen that would significantly dampen asymmetric shocks in the euro area, but as compared for example with the US it will remain unsatisfactory with regard to both private and public sector mechanisms. This makes the proposal in the present paper interesting as it could fill this gap at least partly.

\subsection{Evaluation of the proposed mechanism}

The theoretical foundations for smoothing asymmetric shocks by some sort of risk sharing devise in a monetary union (Farhi and Werning 2014) are quite clear, but practical solutions that would have gained the necessary political acceptance have not appeared. Our hypothesis is that this is caused by the suspicion of short-term money transfers turning into persistent redistribution. This is quite understandable. The politicians who should decide on them are liable to their national parliaments and they know that the electorates do not accept losing money, especially if the recipients can be labelled as wrong-doers. And those who give weight to common European interests know that 
creating something which unintentionally leads to redistribution will only backfire and make the European project less popular.

The main feature of the proposal in the present paper is that it addresses this obstacle. The rule that over a specified period the net balances of each member states are cleared removes it. This rule somewhat reduces the smoothing effect, but this is the cost of suspicion that cannot be fully removed but only dealt with by this new rule. If it is an intrinsic part of the mechanism, the politicians are able to assure their parliaments that smoothing is strictly separated from redistribution, and they need not rely on the argument that under normal circumstances redistribution would be small.

Clearing the balances over a specified period also removes the moral hazard issues, which always pose a difficulty in designing transfer and insurance schemes: when the governments know that over a few years they will not gain at the expense of the others, the incentives to run responsible policies prevail.

The second important feature of the proposed mechanism is that it induces some degree of additional short-term flexibility to the current rules on fiscal discipline. The transfers feed into the government accounts and make the budget deficit ceiling more binding in the boom and give some room for builtin stabilisers in a recession. This flexibility would follow without modifying the excessive deficit procedure which, as the icon of fiscal discipline, has turned out to be too difficult to touch, even though its rigidity is commonly understood to be suboptimal. ${ }^{20}$

It should be made clear that the proposed mechanism only deals with asymmetries across the member states and it does not (at least directly) solve the issues with the aggregate fiscal stance in the euro area. This is a strong limitation, but at the same time it can be a strength of the proposal in the sense that it tackles the first issue and makes it easier to deal with the second.

In this situation it is sensible to work out what can be done under the current EU Treaty. The first task is to remove the pro-cyclicality in fiscal policy observed over the history of the euro. This could be achieved by applying reasonable flexibility and intelligence under the current rules (at the limit, adjustment for major pensions reforms could be done by a change to the protocol on the EDP). It should be emphasised, however, that this requires that long-term sustainability in all countries is credibly assured. This requirement can be hard to fulfil, but establishing new institutions would hardly be a substitute for lacking trust.

Our proposal for a simple transfer mechanism could obviously be established by a legally simple procedure without changing the EU Treaty. Without being a silver bullet, it would support and supplement the more comprehensive vision of fiscal policy above by helping to dampen asymmetric shocks. As the smoothing mechanisms operating in other monetary unions will not be present in the euro area, the tailor-made transfer mechanism proposed here fills the gap for short-term smoothing. As it is costless and does not lead to permanent redistribution, there should not be strong objections to it, even if its effects were somewhat smaller than some ideal hypothetical insurance schemes.

20 Hebous and Weichenrieder $(2015,4,15)$ argue that transfer mechanisms where permanent redistribution is eliminated (by clawbacks as proposed for the unemployment insurance schemes) are not needed as the transfers received shrink to borrowing to be paid back, so that fluctuation in deficits of the member states would equally do the job. However, as also they point out, this argument fully holds only if government borrowing were unconstrained. As this is not the case we should conclude that the mechanism proposed here contributes to smoothing both directly and by providing flexibility to implementation of the EDP/SGP. 
The main rule that the balances be always cleared in an orderly fashion helps in finding the necessary political support, even if some details were not fully settled. For example, the output gap estimates need to be improved and possible other indicators for determining the transfers could be investigated further by experts, but this does not mean that establishing the proposed mechanism should be delayed. Here, the strict rule that no permanent transfers are created makes it possible for all parties to accept to start with some reasonable basis for the transfers, which can even be preliminary, and improve them later if better indicators become available. No country would anyway lose or win over two seven-year periods from the revision of the indicator(s) used.

\section{Summary and conclusions}

In planning for a monetary union for the European Community, subsequently for the EU, the following questions were and still remain of key importance: (1) how much redistribution of income in favour of the less advanced member states is required and (2) what degree of smoothing of the effects of asymmetric shocks across the members is required for a well-functioning single currency area. Nearly 40 years ago the famous MacDougall report of 1977 addressed these questions, but until today conclusive answers are missing. In the present paper we take the view that this follows partly from deficient conceptual clarity. The two questions are interrelated, but they should be kept analytically distinct in order to design practical and politically acceptable solutions for both of them.

In the 1990s it was made clear that politically acceptable redistribution of income across the EU member states is only a small fraction of corresponding transfers within unitary nation states and federations which have a significant centralised budget (the US and Germany as examples).

When the economic and monetary union for the EU was negotiated, there was intensive debate of mechanisms to make the single currency work smoothly. Limited redistribution in favour of less advances member states was adopted in Maastricht in 1991 in parallel with the agreed gradual transition to the single currency. However, no specific mechanisms for smoothing asymmetric shocks were introduced to the plan as it became a dominant view that the monetary union would by itself lead to more integration of the economies so that asymmetric developments would diminish.

Since the ongoing financial and economic crisis started in 2008 it was recognised that the euro area economies had, on the contrary, developed in diverse directions and that fiscal policies had been procyclical rather than dampening asymmetric developments.

The report of the five presidents of the EU institutions in June 2015 contains their vision on completing Europe's Economic and Monetary Union. In their language the 'Fiscal Union' should deliver both fiscal sustainability and fiscal stabilisation. Stabilisation refers in their report both to the fiscal stance in the euro area in general and to smoothing the effects of asymmetric shocks. Regarding the latter, the report relies primarily on risk-sharing in the private sectors. Quite rightly, its role can be expected to grow, but one can also have doubts about the speed at which the financial and capital markets will become integrated so deeply that private risk-sharing only would be sufficient. This is recognised also in the report of the presidents as they note that in the medium term also 'public risksharing' should be enhanced. The report leaves the exact design for more in-depth work, obviously because clearly expressed proposals were not available. It also states that some legally binding 'convergence', which is left obscure, would be a condition for each euro area member state to participate in it. This may not be a promising way to improve functioning of the euro. 
The most recent high-level report, the Communication from the European Commission (2015) in October indicates that not much progress can be expected in near future: presenting a White Paper on more fundamental improvements was postponed until spring 2017. Also, the volume of leading economists entitled How to fix Europe's monetary union (Baldwin and Giavazzi, eds, 2016) published at the time of finalising the present paper leaves much further work for academics.

$* * * * * * * * * * * * * * * * * * * * * * * * * * *$

In the US redistribution and some smoothing of asymmetric shocks across the states takes place through the federal budget, while smoothing resulting from private sector risk-sharing is more significant. In the euro area a centralised budget is virtually non-existent and smoothing via private capital and financial markets is tiny and will at best develop only slowly. This means that there are clear arguments for designing a mechanism which works at the level of government budgets.

The present proposal responds to this need. Under the proposed transfer mechanism the countries pay into and receive from a common pool according to their cyclical position compared to the euro area average. The relative cyclical position can be measured by output gap data.

$* * * * * * * * * * * * * * * * * * * * * * * * * *$

In the euro area the general government budgets are large, which in principle makes it possible that the automatic stabilisers could significantly dampen both common and asymmetric shocks. However, suspicion and mistrust among the euro area member states appear to be causing excessive rigidity, even pro-cyclical fiscal policies in the past. Policy has focussed on fiscal discipline in the short term, guided by the rules under the excessive deficit procedure (EDP) in the Maastricht Treaty. Further rigidity was brought about with the Stability and Growth Pact (SGP) as Germany could not trust that all euro area partners would conduct sound and responsible fiscal policies.

Rigidity in fiscal policy cannot be removed easily because defining long-term sustainability of public finances that could give leeway for short-term flexibility is a genuinely difficult task, which is not easily accomplished jointly in the EU. Work to make progress on this front should continue. However, as the public finances are now even weaker than before the crisis and it will take quite some time to improve them, there is a danger that flexibility for cushioning shocks may decrease even further and fiscal policy turn more pro-cyclical.

Suspicion and mistrust also obstruct designing mechanisms for smoothing short-term shocks as the governments fear that the transfers might develop into permanent redistribution. Even relatively limited transfers are regarded politically unacceptable as they are specifically recorded in government accounts as compared with the less clear-cut benefits of economic integration.

$* * * * * * * * * * * * * * * * * * * * * * * * * *$

In order to overcome these problems caused by mistrust we present here a novel proposal. As a means for removing suspicion of persistent and permanent redistribution we propose an overarching rule that the mechanism be run in periods of, for example, seven years, and after each period the cumulative balance of each country is recorded and cleared in equal instalments during the subsequent 7-year period. This rule assures that no persistent or permanent redistribution takes place, ensuring that all redistribution takes place under the separate measures agreed and established for their purposes. 
The transfers under the proposed mechanism would help smoothing asymmetric shocks. In addition, they would alleviate the rigidity of the deficit rules under the EDP/SGP. This would make government budgets more flexible in the short term, allowing built-in stabilisers to work. Equally importantly, the mechanism would not diminish the need to assure long-term sustainability of public finances.

The proposed mechanism is practically costless, and it requires almost no administrative capacity as it is virtually automatic. It does not require any tangible delegation of decision making powers to EU institutions and it could be established under a relatively simple legal procedure. An agreement on the key parameters is needed, but the details could be fine-tuned without great political obstacles as it would always be made sure that the net balances of all member states be cleared during the next seven-year period, even if the details for determining the annual transfers were adjusted meanwhile. The mechanism would not create so-called moral hazard problems that commonly disturb transfer and insurance systems as the participants try to benefit at the expense of the others.

$* * * * * * * * * * * * * * * * * * * * * * * * * *$

An illustration based on past data shows that the mechanism would obviously have had an overall smoothing effect on the euro area economies in the past 20 years. The proposed mechanism would be virtually costless, and it would help the euro to serve its important economic functions without a significant centralised budget. Yet, it would significantly improve the functioning of the euro area as a monetary union. Therefore, finding broad support for it should not be difficult. It would help the policy makers to concentrate on other important aspects of euro area fiscal policy and in its member states, like setting the appropriate fiscal stance for the euro area as a whole and improving long-term sustainability of public finances in each country. As the proposed mechanism for cushioning asymmetric shocks can remain decentralised, the member states and EU institutions can focus on performance of the euro area as a whole and on other tasks where European integration most efficiently brings additional value.

\section{References}

Allard, C., P.K. Brooks, J.C. Bluedorn, F. Bornhorst, K. Christopherson, F. Ohnsorge and T. Poghosyan (2013), "Toward a Fiscal Union for the Euro Area", IMF Staff Discussion Note 13/09, September 2013.

Allard, C., J. Bluedorn, F. Bornhorst and D. Furceri (2015), "Lessons from the crisis: Minimal elements for a fiscal union in the euro area", in Designing a European Fiscal Union, Lessons from the experience of fiscal federations, Edited by C. Cottarelli and M. Guerguil, Routledge, London and New York, 60-89, 224-252.

Andor, L. (2014), "Basic European Unemployment Insurance - The Best Way Forward in Strengthening the EMU's Resilience and Europe's Recovery", Intereconomics, 184-189, DOI: 10.1007/s10272-014-05004.

Artus, P., A. Bénassy-Quéré, L. Boone, J. Cailloux, J. Delpla, E. Farhi, P. Gourinchas, J. Tirole and G. Wolff (2013), "Completing the Euro", French Council of Economic Analysis, Les notes du Conseil d'Analyse Économique, No 3, April, 2013.

Asdrubali, P., B.E. Sørensen and O. Yosha (1996), "Channels of interstate risk sharing: United States 19631990", The Quarterly Journal of Economics, November 1996: 1081-1110.

Baldwin, R. and F. Giavazzi, eds, (2015), The Eurozone Crisis, A Consensus View of the Causes and a Few Possible Remedies, A VoxEU.org eBook, Centre for Economic Policy Research (CEPR). 
Baldwin, R. T. Beck, A. Bénassy-Quéré, O. Blanchard, G. Corsetti, P. de Grauwe, W. den Haan, F. Giavazzi, D. Gros, S. Kalemli-Ozcan, S. Micossi, E. Papaioannou, P. Pesenti, C. Pissarides, G. Tabellini and B. Weder di Mauro (2015), "Rebooting the Eurozone: Step 1 - agreeing a crisis narrative", CEPR Policy Insight No 85, November 2015.

Baldwin, R. and F. Giavazzi, eds, (2016), How to fix Europe's monetary union: Views of leading economists, A VoxEU.org eBook, Centre for Economic Policy Research (CEPR).

Baldwin, R. and F. Giavazzi (2015), "Introduction”, in Baldwin and Giavazzi, eds, (2015), 18-62.

Baldwin, R. and F. Giavazzi (2016), "Introduction”, in Baldwin and Giavazzi, eds, (2016), 22-32.

Bargain, O., M. Dolls, C. Fuest, D. Neumann, A. Peichl, N. Pestel and S. Siegloch (2012), "Fiscal Union in Europe? Redistributive and Stabilising Effects of an EU Tax-Benefit System”, IZA Discussion Paper No. 6585, May 2012; published also in Economic Policy, July 2013, 375-422.

Beblavý, M. and I. Maselli (2014), “An Unemployment Insurance Scheme for the Euro Area: A simulation exercise of two options, CEPS Special report No. 98, December 2014.

Beetsma, R. and H. Oksanen (2008), "Pensions under Ageing Populations and the EU Stability and Growth Pact”, CESifo Economic Studies 54, 4/2008, 563-592.

Bielawska, K., A. Chłoń-Domińczak and D. Stańko (2015), "Retreat from mandatory pension funds in countries of the Eastern and Central Europe in result of financial and fiscal crisis: Causes, effects and recommendations for fiscal rules", Warsaw, June 2015.

Bofinger, P. (2016), "The way forward: Coping with the insolvency risk of member states and giving teeth to the European Semester", in in Baldwin and Giavazzi, eds, (2016), 227-239.

Committee for the study of EMU (1989), "Report on economic and monetary union in the European Community", the Jacques Delors Report, Luxembourg.

Commission of the EC (1977), "Report of the study group on the role of public finance in European integration", Economic and Financial series, No A13 (MacDougall report).21

Commission of the EC (1990a), "Economic and monetary union", Commission communication of 21 August 1990, Luxembourg.

Commission of the EC (1990a), "Economic and monetary union", Commission communication of 21 August 1990, Luxembourg.

Commission of the EC (1990b), "One market, one money", European Economy, 44.

Commission of the EC (1993), "Stable money - sound finances, Community public finance in the perspective of EMU”, European Economy, 53.

Cottarelli, C. and M. Guerguil (2015), "Introduction and overview", in Designing a European Fiscal Union, Lessons from the experience of fiscal federations, Edited by Carlo Cottarelli and Martine Guerguil, Routledge, London and New York, 1-12.

Court of Justice of the European Union (2004) "Case C-27/04, Judgment of the Court", 13 July 2004.

Court of Justice of the European Union (2015a), "The OMT programme announced by the ECB in September 2012 is compatible with EU law", Press Release No 70/15, Judgement in Case C-62/14, Luxembourg, 16 June 2015.

Court of Justice of the European Union (2015b), "Judgement of the Court, Case C-62/14”, 16 June 2015.

De Grauwe, P. and Y. Ji (2016), "How to reboot the Eurozone and ensure its long-term Survival”, in Baldwin and Giavazzi, eds, (2016), 136-150.

21 Officially "Commission of the European Communities". It appears on the publications until 1993 when it changed to "European Commission" which then appears also in this list below. 
Delors, J. (1989), "Regional implications of economic and monetary integration, in Collection of papers, chapter III in Committee for the study of EMU (1989), 81-89.

Dolls, M., C. Fuest and A. Peichl (2012), "Automatic stabilization and discretionary fiscal policy in the financial crisis", IZA Journal of Labor Policy, 2012, 1:4, 1-19.

Dolls, M., C. Fuest, F. Heinemann and A. Peichl (2016), "Reconciling Insurance with Market Discipline: A Blueprint for a European Fiscal Union", CESifo Working Paper No 5767, February; CESifo Economic Studies, first published online March 15, 2016 doi:10.1093/cesifo/ifw004.

Doukas, D. (2005) "The Frailty of the Stability and Growth Pact and the European Court of Justice: Much Ado about Nothing?", Legal Issues of Economic Integration 32(3): 293-312.

Dullien, S. (2012), “A European unemployment insurance as a stabilization device - Selected issues", Paper prepared for the Seminar 'EU level economic stabilisers'.

Dullien, S. (2013), "A euro-area wide unemployment insurance", paper prepared for the European Commission, Directorate-General Employment, Social Affairs \& Inclusion.

Dullien, S. (2014), "The Macroeconomic Stabilisation Impact of a European Basic Unemployment Insurance Scheme", Intereconomics, 189-193, DOI: 10.1007/s10272-014-0500-4.

Eichengreen, B. and C. Wyplosz (2016a), "Minimal conditions for the survival of the euro", in Baldwin and Giavazzi, eds, (2016), 33-45.

Eichengreen, B. and C. Wyplosz (2016b), "How the Euro Crisis was successfully resolved", in Baldwin and Giavazzi, eds, (2016), 240-247.

Enderlein, H. (coordinator), P. Bofinger, L. Boone, P. de Grauwe, J.-C. Piris, J. Pisani-Ferry, M. J. Rodrigues, A. Sapir and A. Vitorino (2012): "Completing the Euro - A road map towards fiscal union in Europe", Report of the 'Tommaso Padoa-Schioppa Group'. Notre Europe - Jacques Delors Institute, Study 92.

Enderlein, H., L. Guttenberg, J. Spiess (2013a), "Making one size fit all, Designing a cyclical adjustment insurance fund for the eurozone", Notre Europe - Jacques Delors Institute, Policy Paper 61, January 2013.

Enderlein, H., L. Guttenberg, J. Spiess (2013b), "Blueprint for a cyclical shock insurance fund for the euro area", Notre Europe - Jacques Delors Institute, Studies and Reports 100, September 2013.

European Commission (1993), "The economics of Community public finance", European Economy, 5.

European Commission (1997), "Agenda 2000, for a stronger and wider Union”, COM(97) 2000 final, 15 July 1997, Bulletin of the European Union, Supplement 5/97.

European Commission (2012), "A blueprint for a deep and genuine economic and monetary union: Launching a European Debate", $\operatorname{COM}(2012) \quad 777$ final/2. http://ec.europa.eu/commission_20102014/president/news/archives/2012/11/pdf/blueprint_en.pdf..

European Commission (2013a), "Paper on automatic stabilisers", DG Employment, Social Affairs and Inclusion. Main authors Olivier Bontout and Guy Lejeune with Magdalena Ciesielska and Roberta Di Girolamo. Brussels, 04 October 2013.

European Commission (2013b), Agriculture in the European Union - statistical and economic information, Report 2013, Brussels

European Commission (2015), “On steps towards Completing Economic and Monetary Union”, COM(2015) 600 final, Brussels, 21.10.2015.

European Parliament (1998a), "Report on the adjustment mechanism in cases of asymmetric shocks", 11 November 1998, A4-0422/98.

European Parliament (1998b), "Minutes of the sitting of Wednesday 16 December 1998".

Eyraud, L. and T. Wu (2015), "Playing by the Rules: Reforming Fiscal Governance in Europe", IMF Working Paper WP/15/67. 
Farhi, E. and Iván Werning (2014), "Fiscal Unions", online manuscript.

Fatás, A. (1998), “Does EMU need a fiscal federation?”, Economic Policy, No 26: 165-203.

Feld, L.P., C.M. Schmidt, I.Schnabel and V. Wieland (2015), "Divergence of liability and control as the source of over-indebtedness and moral hazard in the European Monetary Union", in Baldwin and Giavazzi, eds, (2015), 185-197.

Feld, L.P., C.M. Schmidt, I.Schnabel and V. Wieland (2016), "Maastricht 2.0: Safeguarding the future of the Eurozone", in Baldwin and Giavazzi, eds, (2016), 46-61.

Financial Times (2015), Eurozone needs independent fiscal oversight, says Dijsselbloem, 4 November, 2015.

Fuest, C, F. Heinemann and C. Schröder (2016), "A Viable Insolvency Procedure for Sovereigns in the Euro Area”, Journal of Common Market Studies 54:2, 301-317, first published online: 27 JUL 2015.

Furceri, D. and A. Zdzienicka (2013), "The Euro Area Crisis: Need for a Supranational Fiscal Risk Sharing Mechanism?” IMF Working Paper No. 13/198.

Goodhart, Ch. A. E. and Smith, S. (1993), "Stabilization", in European Commission (1993): 417-455.

Gros, D. (2014), "A fiscal shock absorber for the Eurozone? Lessons from the economics of insurance", VOX, CEPR's Policy Portal, 19 March 2014.

Györffy, D. (2013), Institutional Trust and Economic Policy: Lessons from the History of the Euro, Central European University Press, Budapest - New York.

Hebous, S. and A. Weichenrieder (2015), "Towards a fiscal union? On the acceptability of a fiscal transfer system in the Eurozone", SAFE Policy Center, House of Finance, Goethe University, White paper 28.

Heipertz, M. and A. Verdun (2010) Ruling Europe: The Politics of the Stability and Growth Pact (Cambridge: Cambridge University Press).

Hers, J. and W. Suyker (2014), "Structural budget balance: A love at first sight turned sour", CPB Netherlands Bureau for Economic Analysis, CPB Policy Brief 2014/07.

Hoffmann, M. and B.E. Sørensen (2012), "Don't expect too much from EZ fiscal union - and complete the unfinished integration of European capital markets!”, VOX, CEPR's Policy Portal, 09 November 2012.

Italianer, A. and Vanheukelen, M. (1993), "Proposals for Community stabilization mechanisms: Some historical applications", in European Commission (1993): 493-510.

Juncker, J.-C. (2015), “Completing Europe's Economic and Monetary Union”, Report in close cooperation with Donald Tusk, Jeroen Dijsselbloem, Mario Draghi and Martin Schulz, 22 June 2015.

Korkman, S. (2005), Economic Policy in the European Union, Palgrave Macmillan, New York.

Lane, P.R. (2015), "International financial flows and the Eurozone crisis", in Baldwin and Giavazzi, eds, (2015), 129-133.

Majocchi, A. and M. Rey (1993), “A special financial support scheme in economic and monetary union: Need and nature", in European Commission (1993), 457-480.

Mc Morrow, K., W. Roeger, V. Vandermeulen and K. Havik (2015), "An assessment of the relative quality of the Output Gap estimates produced by the EU's Production Function Methodology", European Commission Directorate-General for Economic and Financial Affairs, Discussion Paper 20, December 2015.

Mélitz, J. and F. Zumer (1998), "Regional redistribution and stabilisation by the centre in Canada, France, The United Kingdom and The United States: new estimates based on panel data econometrics", CEPR Discussion Paper No 1829, February 1998.

Obstfeld, M. and G. Peri (1998), "Regional non-adjustment and fiscal policy", Economic Policy, No 26: 205259. 
Oksanen, H. (2013): Pensions and European Integration, Chapter 11 in A. Verdun and A. Tovias, eds, Mapping European Economic Integration, Houndmills Basingstoke: Palgrave Macmillan. ISBN: 978-0-23035615-3.

Palme J., I. Esser, T. Ferrarini, K. Nelson and O. Sjöberg (2013), "Unemployment benefits in EU Member States", Paper prepared for the European Commission, Directorate-General Employment, Social Affairs \& Inclusion.

Pisani-Ferry, J. (2016), “The Eurozone's Zeno paradox - and how to solve it”, in Baldwin and Giavazzi, eds, (2016), 75-86.

Pisani-Ferry, J., A. Italianer and R. Lescure (1993), "Stabilization properties of budgetary systems: A simulation analysis", in European Commission (1993): 511-538.

Poghosyan, T., S. Abdelhak and C. Cottarelli (2015), "The role of fiscal transfers in smoothing regional shocks", in Designing a European Fiscal Union, Lessons from the experience of fiscal federations, eds, C. Cottarelli and M. Guerguil, Routledge, London and New York, 60-89.

Rehn, O. (2012), Myrskyn silmässä, Otava, Keuruu.

Sachs, J. and X. Sala-i-Martin (1989), "Federal fiscal policy and optimum currency areas", Harvard University, mimeo.

Sachs, J. and X. Sala-i-Martin (1992), "Fiscal Federalism and Optimum Currency Areas: Evidence for Europe from the United States," in Establishing a Central Bank: Issues in Europe and Lessons from the U.S., eds, M. Canzoneri, V. Grilli, and P. Masson (Cambridge: Cambridge University Press).

Schmidt, S.K. (2013), “A sense of déjà vu? The FFC's preliminary European Stability Mechanism Verdict", German Law Journal, Vol. 14 No. 01, 01 January 2013, 1-20.

Sinn, H.-W. (2012), “TARGET losses in case of a euro breakup”, VOX CEPR's Policy Portal, 22 October, 2012.

Sørensen, B.E. and O. Yosha (1998), "International risk sharing and European monetary unification”, Journal of International Economics, 45: 211-238.

Sutherland, H. (2012), "Social economic stabilisers in the European Union", Paper prepared for the Seminar "EU level economic stabilisers" (2nd July 2012), draft: 19" June 2012.

The Telegraph (2016), Mervyn King: the eurozone is doomed, 28 February 2016.

Towards a fiscal union for the euro area (2013), International Monetary Fund, technical background notes to Allard et al. (2013), September 2013.

Tuori, Kaarlo and Klaus Tuori (2014), The Eurozone Crisis, A Constitutional Analysis, Cambridge Studies in European Law and Policy, Cambridge University Press.

Van der Ploeg, F. (1991), "Macroeconomic policy coordination issues during the various phases of economic and monetary integration in Europe", European Economy Special Edition 1: 136-164.

Van Rompuy, H. (2012), “Towards a genuine Economic and Monetary Union”, Report in collaboration with José Manuel Barroso, Jean-Claude Juncker and Mario Draghi, Brussels, 5 December, 2012 http://www.consilium.europa.eu/uedocs/cms_data/docs/pressdata/en/ec/134069.pdf

Van Rompuy, P., F. Abraham and D. Heremans (1991), "Economic federalism and the EMU", European Economy Special Edition 1: 109-135.

von Hagen, J., (1992), "Fiscal Arrangements in a Monetary Union: Evidence from the US" in Fiscal Policy, Taxes, and the Financial System in an Increasingly Integrated Europe, edited by Don Fair and Christian de Boissieux (London: Kluwer).

von Hagen, J., and G.W. Hammond. 1998. "Regional Insurance against Asymmetric Shocks: An Empirical Study for the European Community." The Manchester School 66 (3): 331-53. 
von Hagen, J. and G.W. Hammond (1998): "Regional Insurance against Asymmetric Shocks: An Empirical Study for the European Community", The Manchester School, 66 (3), 331-353.

von Hagen, J. (2007): “Achieving Economic Stabilization by Sharing Risk within Countries", in R. Boadway and A. Shah, eds, Intergovernmental Fiscal Transfers. Washington, DC: World Bank, 107-132.

Weder di Mauro, B. (2015), "Causes of a continuing crisis: Not dealing with debt", in in Baldwin and Giavazzi, eds, (2015), 176-184.

Wolff, G.B. (2012). “A Budget for Europe’s Monetary Union,” Bruegel Policy Contribution, 2012/22.

Wyplosz, C. (1991), "Monetary Union and Fiscal Policy Discipline." European Economy Special Edition 1: $165-84$.

Wyplosz, C. (2015), “The Eurozone crisis: Too few lessons learned”, in Baldwin and Giavazzi, eds, (2015), 198-204.

\section{Online sources}

https://en.wikipedia.org/wiki/Economic_history_of_the_German_reunification gives estimates of transfers from the German federal budget to former GDR Länder with reference to Ghaussy and Schäfer, The Economics of German unification (1993), p. 41.

https://en.wikipedia.org/wiki/List_of_U.S._states_by_income gives statistics on per capita production and income by US states.

https://en.wikipedia.org/wiki/Rate_schedule_(federal_income_tax) gives the US federal income tax schedule.

EurActiv.com, 23 Feb 2015, "Giscard: 'Greece should leave the euro, not the EU”, online

http://www.euractiv.com/sections/euro-finance/giscard-greece-should-leave-euro-not-eu-312272.

\section{Abbreviations}

$\mathrm{EU}=$ European Union. The EU member states in the order they appear in official EU documents (alphabetic order according to their names in native languages):

\begin{tabular}{|l|l|l|l|l|l|l|l|}
\hline Belgium & (BE) & Greece & EL) & Lithuania & (LT) & Portugal & (PT) \\
\hline Bulgaria & (BG) & Spain & (ES) & Luxembourg & (LU) & Romania & (RO) \\
\hline Czech Republic & (CZ) & France & (FR) & Hungary & (HU) & Slovenia & (SI) \\
\hline Denmark & (DK) & Croatia & (HR) & Malta & (MT) & Slovakia & (SK) \\
\hline Germany & (DE) & Italy & (IT) & Netherlands & (NL) & Finland & (FI) \\
\hline Estonia & (EE) & Cyprus & (CY) & Austria & (AT) & Sweden & (SE) \\
\hline Ireland & (IE) & Latvia & (LV) & Poland & (PL) & United Kingdom & (UK) \\
\hline
\end{tabular}

EUR = euro,

EUR-12: 11 EU member states that adopted the euro in 1999 (BE, DE, IE, ES, FR, IT, LU, NL, AT, PT and

FI, and EL which joined it in 2001,

$\mathrm{EC}=$ European Communities,

$\mathrm{ECB}=$ European Central Bank,

$\mathrm{EDP}=$ excessive deficit procedure,

$\mathrm{EMU}=$ economic and monetary union,

$\mathrm{ESM}=$ European stability mechanism,

FTEU $=$ Treaty on the Functioning of the European Union,

OMT $=$ Outright Monetary Transactions,

SGP = stability and growth pact,

TARGET2 replaced TARGET $=$ Trans-European Automated Real-time Gross Settlement Express Transfer System in November 2007; it is an interbank payment system for the real-time processing of crossborder transfers throughout the EU.

A number of abbreviations (GDP, GNI, IMF, OECD etc.) have their conventional meanings. 